\title{
Evolution of Frequency and Intensity of Concurrent Heavy Precipitation and Storm Surge at the Global Scale: Implications for Compound Floods
}

\author{
Yangchen $\mathrm{Lai}^{1,2,3,4}$, Qingquan $\mathrm{Li}^{1 *}$, Jianfeng $\mathrm{Li}^{2,3,4 *}$, Qiming Zhou ${ }^{2,4}$, Xinchang Zhang ${ }^{5}$ and \\ Guofeng $W u^{1}$
}

${ }^{1}$ MNR Key Laboratory for Geo-Environmental Monitoring of Great Bay Area, Shenzhen University, Shenzhen, China, ${ }^{2}$ The Centre for Geo-computation Studies and Department of Geography, Hong Kong Baptist University, Hong Kong, China, ${ }^{3}$ GuangdongHong Kong Joint Laboratory for Water Security, Hong Kong, China, ${ }^{4}$ Institute for Research and Continuing Education, Hong Kong Baptist University, Shenzhen, China, ${ }^{5}$ School of Geography and Remote Sensing, Guangzhou University, Guangzhou, China

\section{OPEN ACCESS}

Edited by:

Abdou Khouakhi,

Cranfield University, United Kingdom

Reviewed by:

Chen Wei-Bo,

National Science and Technology Center for Disaster Reduction (NCDR),

Taiwan

Md Mamunur Rashid, University of Central Florida,

United States

Dirk Eilander.

Deltares, Netherlands

${ }^{*}$ Correspondence:

Qingquan Li

liqq@szu.edu.cn

Jianfeng $L i$

jianfengli@hkbu.edu.hk

Specialty section: This article was submitted to Geohazards and Georisks,

a section of the journal

Frontiers in Earth Science

Received: 29 January 2021 Accepted: 07 July 2021

Published: 20 July 2021

Citation:

Lai Y, Li Q, Li J, Zhou Q, Zhang X and Wu G (2021) Evolution of Frequency and Intensity of Concurrent Heavy Precipitation and Storm Surge at the

Global Scale: Implications for

Compound Floods.

Front. Earth Sci. 9:660359. doi: 10.3389/feart.2021.660359
Compound flood raised from the concurrent heavy precipitation and storm surge receives increasing attention because of its potential threat to coastal areas. Analyzing the past changes in the characteristics of compound flood events is critical to understand the changing flood risks associated with the combination of multiple drivers/hazards. Here, we examined the evolution of the compound flood days (defined as days of concurrent extreme precipitation and extreme storm surge exceeding the 90th percentiles) based on the observed precipitation and storm surge data across the globe. Results show that the annual number of compound flood days increased significantly by $1-4$ per decade $(\alpha=0.1)$ on the east coast of the US and northern Europe, while the annual number of compound flood days decreased significantly in southern Europe and Japan. The increasing trends in precipitation under extreme storm surge and storm surge under extreme precipitation were found extensively across the world except in Japan, suggesting that more intense precipitation appeared when extreme storm surges occurred, and higher storm surge emerged when extreme precipitation occurred. Comparatively, the global fractional contributions of storm surge (i.e., 65\%) on changes in compound flood days were higher than that of precipitation (i.e., 35\%), demonstrating that storm surge was more likely to dominate the changes in the number of compound flood days. This study presents the spatial and temporal characteristics of the compound flood events at the global scale, which helps better understanding the compound floods and provides scientific references for flood risk management and an indispensable foundation for further studies.

Keywords: compound flood, extreme precipitation, storm surge, interannual variability, climate change

\section{INTRODUCTION}

Floods can be classified into three types according to different triggering mechanisms: 1) fluvial floods caused by precipitation over an extended period (riverine floods); 2) pluvial floods due to highintensity and short-duration rainstorms (waterlogging floods); and 3) coastal floods resulting from the extreme sea levels associated with storm surge and high tides (Huntingford et al., 2014). Different 
types of floods can co-occur in certain weather conditions, for example, the concurrence of heavy rainfall and storm surge caused by tropical cyclones (Wahl et al., 2015; Ikeuchi et al., 2017; Lai et al., 2020). These combinations of two or more different floods are referred to as compound floods.

Compound floods are highly risky because the interplay among multiple extremes can exacerbate the adverse impacts (Intergovernmental Panel on Climate Change, 2012; Leonard et al., 2014; Zscheischler et al., 2018; Raymond et al., 2020). For their privilege of proximity to the sea, coastal areas are usually the most densely populated and economically developed areas of a country, and they are also the most vulnerable regions to the risk of compound floods from heavy precipitation and storm surge exactly because of the high population and property density as well as the special location (Chan et al., 2012; Neumann et al., 2015). For examples, Hurricane Harvey in 2017 caused heavy rainfall exceeding $1,000 \mathrm{~mm}$ and extreme storm surge higher than $1.8 \mathrm{~m}$ (Emanuel, 2017; Zhang et al., 2018a); and severe flooding was developed from the storm surge and rainfall during super typhoon Hato in Macau, 2017 (Hong Kong Observatory, 2017; Wang et al., 2019). These two compound floods led to recordbreaking economic damages and life losses (Hong Kong Observatory, 2017; Klotzbach et al., 2018). Given the substantial damage caused by compound floods, a better understanding of the characteristics and driven mechanisms of compound floods is urgently needed.

Even though compound floods can occur coincidently, the dependence among different types of floods has been widely evidenced. For examples, Svensson and Jones (2002), Svensson and Jones (2004) analyzed the dependence among precipitation, river flow, and storm surge; Zheng et al. (2013) identified the significant dependence between precipitation and storm surge along the coastlines of Australia; and at the global scale, Ward et al. (2018) assessed the dependence between high sea level and high river discharge in most areas across the globe. The correlations among precipitation, river flow, and storm surge are determined by various factors such as meteorological conditions and regional topography. For example, the compound floods from heavy precipitation and storm surge can occur in certain weather conditions. In general, the weather conditions associated with compound floods are characterized by deep low pressure, cyclonic winds, and high precipitable water content, which can be found in storm systems (Wahl et al., 2015; Bevacqua et al., 2019). Therefore, storms (including tropical cyclones and extratropical cyclones) are one of the most important triggers of compound floods from heavy rainfall and storm surge (Wahl et al., 2015; Booth et al., 2016; Ikeuchi et al., 2017). The meteorological forcings-caused correlation between precipitation and storm surge can be identified between stations hundreds of kilometers far away (Zheng et al., 2013). The regional topography can also significantly impact the correlation among precipitation, river flow, and storm surge. For instance, the strong dependence between precipitation and storm surge is more likely to be found in hilly coastal areas, and the dependence between storm surge and river flow will be stronger in the steep catchments because of the shorter time required by peak flow to reach the estuary (Svensson and Jones, 2002; Svensson and Jones, 2004).
It's vital to take account of the dependencies among different floods when assessing the compound flood risk because ignoring these dependencies would result in considerable underestimation of compound flood risk. By constructing the joint distribution, previous studies have assessed the potential risk of compound floods from precipitation, river discharge, and storm surge at the regional and global scale (e.g., Moftakhari et al., 2007; Moftakhari et al., 2019; Lian et al., 2013; Van Den Hurk et al., 2015; Wahl et al., 2015; Bevacqua et al., 2017, Bevacqua et al., 2019; Bevacqua et al., 2020a; Bevacqua et al., 2020b; Xu et al., 2019; Couasnon et al., 2020). The regional studies on evaluation of compound flood risks were mainly concentrated on the US and Europe, where the tide gauges are densely distributed and have the best data completeness in a longer period (e.g., Moftakhari et al., 2007; Wahl et al., 2015; Bevacqua et al., 2017, 2019). Besides, some studies assessed the risk of compound floods using hydrodynamic models (e.g., Lian et al., 2013; Ikeuchi et al., 2017; Moftakhari et al., 2019; Gori et al., 2020; Jane et al., 2020; Khanam et al., 2021). These studies, better considered the interactions between flood drivers and localized features, however, were limited to analysis of regional compound flood cases. Constrained by the available data, the global-scale studies based on long-term observations are rare. However, a number of global studies have recently emerged benefitting from the development of simulated storm surge data (Bevacqua et al., 2020a; Bevacqua et al., 2020b; Couasnon et al., 2020; Ridder et al., 2020). These studies provided valuable information of compound floods in the areas where observations were absent (e.g., the coastal area of South America and Africa) but contained substantial uncertainties. Furthermore, Bevacqua et al. (2019), Bevacqua et al. (2020b) projected that driven by the changes in extreme precipitation and meteorological tide under the high emissions scenario, the compound flood risks would increase generally by $>25 \%$ by the end of this century. These studies have well assessed the risk of compound floods; however, rare studies illustrated the evolutions of occurrences of compound floods based on long-term observations.

In this study, the evolutions in concurrences of heavy precipitation and extreme storm surge were analyzed based on the observed precipitation and storm surge data across the globe. The main research questions we aimed to address are as follows: 1) How's the spatial distribution of compound floods? Which areas of the world are the most susceptible to compound floods? In which season do most compound floods occur? 2) What is the interannual variability of compound floods in past decades? And how're the contributions of precipitation and storm surge to the interannual variability? 3) What could be the meteorological drivers causing the changes in compound floods? The answers are critical to understanding the changing compound flood risks, and serves as a scientific reference for flood risk management and an indispensable foundation for further studies.

\section{DATA AND METHODS}

\section{Data}

The compound floods from heavy precipitation and extreme storm surge were analyzed based on the observed precipitation 


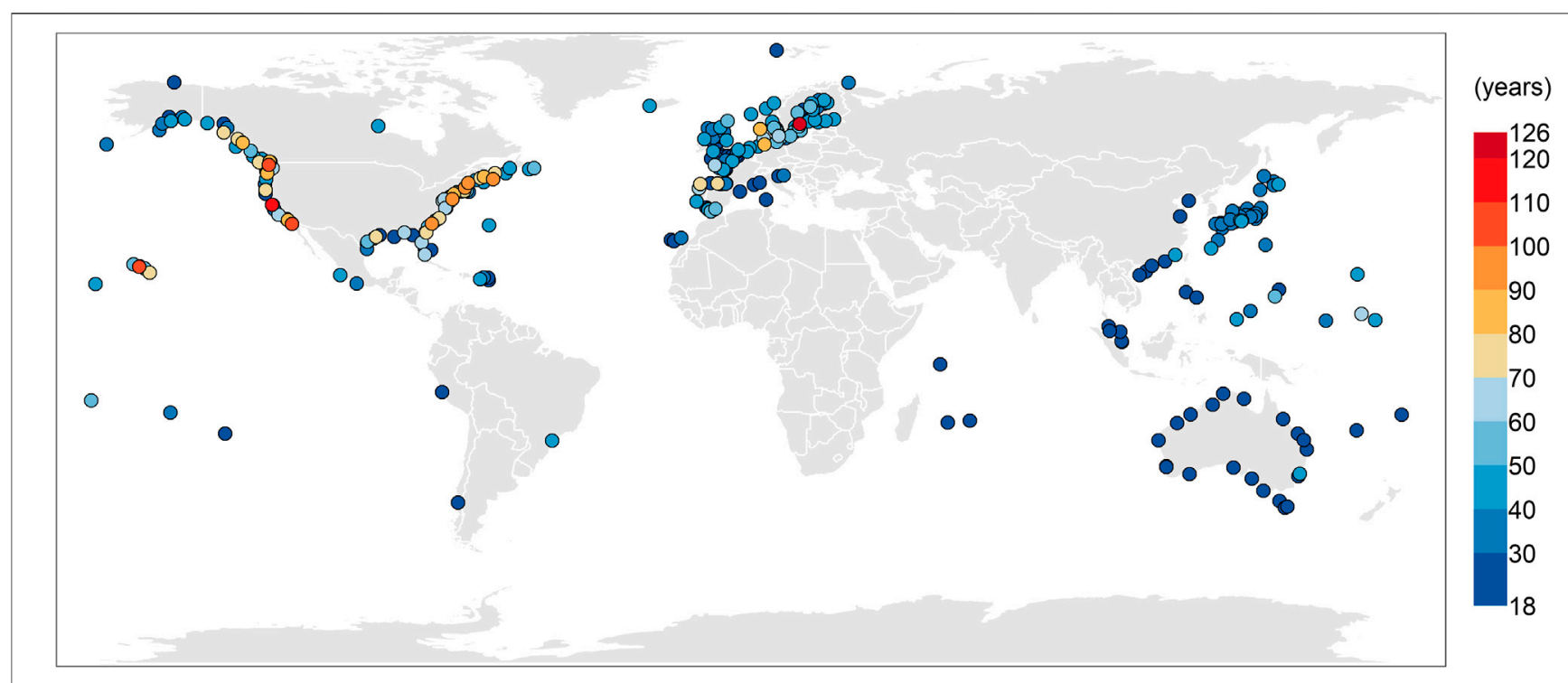

FIGURE 1 | Locations of tide gauges and the number of overlapping years. Only tide gauges with $\geq 18$ overlapping years were used in this study.

and storm surge data. The observed hourly sea level data were obtained from the Global Extreme Sea Level Analysis version 2 (GESLA-2, https://www.gesla.org/; Woodworth et al., 2016). The observed sea level consists of mean sea level, astronomical tides, and non-tidal residual (i.e., storm surge and waves), in which the astronomical tides are caused by the gravitational effects of the moon and the sun, while the storm surge and waves are meteorological phenomena driven by atmospheric pressure and wind (Karim and Minura, 2008; Vousdoukas et al., 2018). Even though the actual water levels causing coastal flood can be estimated as the superpositions of extreme storm surge and astronomical high tides (Bevacqua et al., 2019; Yu et al., 2019), the astronomical tides are not likely to have relationships with meteorologically driven factors such as storm surge and precipitation. Therefore, we used the non-tidal residual to represent the storm surge to better investigate the meteorological drivers that cause the changes in compound floods as many previous studies did (e.g., Bevacqua et al., 2020a, Bevacqua et al., 2020b; Couasnon et al., 2020; Ridder et al., 2020; Wahl et al., 2015; Zheng et al., 2013). To extract the storm surge component, we applied a tidal harmonic analysis (T-tide; Pawlowicz et al., 2002) to analyze the observed sea level of each year to remove the impact of mean sea level rise. Hence, hourly storm surge data was converted to daily time series by extracting the daily maxima.

Daily precipitation data of more than 4,900 stations with the record lengths varying from 18 to 126 years were obtained from the Global Historical Climatology Network (GHCNDaily, https://www.ncdc.noaa.gov/ghcn-daily-description; Menne et al., 2012). For each tide gauge, the average precipitation of all stations within a radius of $25 \mathrm{~km}$ from the tide gauge was used (Wahl et al., 2015). In the case there was no precipitation station within $25 \mathrm{~km}$ from the tide gauge, the search radius was expanded to $50 \mathrm{~km}$. The years with $>25 \%$ missing days were discarded. To assess whether the choice of precipitation average method would affect our analysis, the results based on precipitation calculated by inverse distance weighted method are shown in Supplementary Material. Only the tide gauges with record lengths $>18$ years over 1979-2014 were considered. 314 tide gauges were selected, and they are mainly located along the coasts of North America, Europe, Australia, East Asia, and Southeast Asia (Figure 1). The atmospheric variables used to analyze the weather conditions associated with compound floods included sea level pressure, three-dimension winds, and precipitable water content at $2.5^{\circ} \times 2.5^{\circ}$ spatial resolution during 1948-2014, and they were obtained from NCEP/NCAR reanalysis dataset (https://www.esrl.noaa.gov/psd/data/ gridded/data.ncep.reanalysis.html; Kalnay et al., 1996).

\section{Methods}

There is no consistent mathematical definition of compound floods, and a widely used definition is based on the annual maxima. For example, Wahl et al. (2015) identified the compound floods from the time series of annual maxima of one variable (e.g., precipitation) and the corresponding block maxima of the other variable (e.g., storm surge). The sample size of compound floods based on this method is small because only one data pair is sampled for each year and each location, which is not ideal for the following statistical analyses of changes in compound floods. An alternative method to define compound floods is based on the peak-overthreshold method, in which, compound floods are usually defined as the co-occurrences of univariate extremes (e.g., extreme precipitation and extreme storm surge) exceeding a given percentile (Bevacqua et al., 2019; Bevacqua et al., 2020b). One advantage of this method is that more compound flood days could be sampled. In this study, the 90th percentiles were used to identify extreme precipitation/storm surge, and compound floods were defined as the co-occurrence of both 
extreme precipitation and extreme storm surge exceeding the percentiles. Here, the storm surge and precipitation data at the same calendar day were paired without consideration of time lag, and each day with precipitation and storm surge exceeding the threshold was taken as a compound flood day. The number of compound flood days was defined as an index to investigate the evolution of the days of concurrent heavy precipitation and storm surge. Indices based on similar definitions (e.g., number of days with precipitation $>75 \mathrm{th}$, 95th, and 99th percentiles) have been widely used in previous studies to detect the changes in extreme events (Fatichi and Caporali, 2009; Li et al., 2013; Zhang et al., 2013).

One drawback of defining compound flood days using the peak-over-threshold method is that the threshold exceedances may occur successively during extreme weather systems (e.g., tropical cyclones), thus not fully respect the independence assumption (Fatichi and Caporali, 2009). However, since the objective of this study is to assess whether the number of compound flood days is changing instead of evaluating the changes in the return period of compound flood events, the dependence between some compound flood days should not substantially affect our results of the trend detection (Fatichi and Caporali, 2009). Besides, a compound flood event that lasts longer might lead to greater damage than that lasts shorter. An increase in compound flood days implies more frequent compound flood events and/or longer durations of compound flood events. In either case, the potential risk of compound floods increases, and vice versa.

Even though using a lower threshold (i.e., 90th percentile) implies that the concurrent extreme precipitation and extreme storm surge may not lead actual compound floods, but it can ensure that enough compound flood days could be sampled to conduct a more robust analysis. The 90 th percentile was widely used as a threshold to define flood events in previous studies (Gemmer et al., 2011; Iannuccilli et al., 2021; Li et al., 2015; Muis et al., 2018; Zhang et al., 2013). Besides, whether an actual flood occurs or not highly depends on localized characteristics such as topography, land use, regional climate, and their interactions (Bevacqua et al., 2020a; Hendry et al., 2019). In this case, we limited our analysis to the compound flood potentials (i.e., probability of occurrences) rather than the actual compound flood to better understanding their changes. To evaluate whether the choice of threshold would affect the analysis, the results with thresholds of 85th and 95th percentiles are shown in Supplementary Material. Considering the non-stationary statistics of hydrometeorological variables under climate change, the probability distribution of a hydrometeorological variable might change over time and hence the statistics of a period can not reflect those of another period (Gu et al., 2017; Milly et al., 2008; She et al., 2015). If we estimate the percentile threshold based on the data in a long period, the statistics of the variable may have altered in the study period (for example, the percentile in an earlier sub-period may be different from that in a later sub-period). To mitigate the impact of non-stationarity, the percentiles of precipitation/storm surge at all stations were estimated based on the daily time series from 1979 to 2014 . This approach is the same as that used in many previous studies about climate extremes (You et al., 2011; Zhai et al., 2005; Zhang et al., 2005). For example, the Expert Team on Climate Change Detection and Indices (ETCCDI; https://www.wcrp-climate.org/etccdi) includes a number of climate extreme indices based on percentile thresholds (Li et al., 2013; Kurniadi et al., 2021). The percentile threshold is calculated from the fixed period of 1961-1990 in ETCCDI (Zhang et al., 2011). For instance, R95pTOT is defined as annual total precipitation when daily precipitation exceeds the 95th percentile in the 1961-1990 period (Dong et al., 2021). The 95th percentile threshold estimated in 1961-1990 is used to identify climate extremes in the past (e.g., before 1961) and the future (e.g., the 21 st century).

The precipitation under extreme storm surge (i.e., precipitation of days with storm surge exceeding the 90th percentile) and storm surge under extreme precipitation (i.e., the storm surge of days with precipitation exceeding the 90th percentile) were analyzed to investigate the relationship between changes in compound floods, precipitation and storm surge. According to our definition of compound floods, the intensity of compound floods is determined by the intensity of precipitation and storm surge height. With this understanding, the changes in precipitation under extreme storm surge and the changes in storm surge under extreme precipitation reflect the changes in the intensity of compound floods. That is, given one of the two variables (e.g., precipitation as an example) exceeds the threshold, the increase (or decrease) in the other variable (e.g., storm surge) indicates the increase (or decrease) in the intensity of a potential compound event. Once the storm surge exceeds the threshold, it is considered a compound flood in this study. Therefore, the changes in the intensity of compound floods can be reflected in terms of 1) the changes of precipitation under extreme storm surge, and 2) the changes of storm surge under extreme precipitation.

The contributions of changes in precipitation and storm surge to the changes in the number of compound flood days were determined by the multivariate regression methodology. This method has been applied in the attribution analysis of changes in soil moisture (Zhang et al., 2018b). The regression equation is written as:

$$
C F^{\prime}=a \times P+b \times S+\varepsilon,
$$

where $C F^{\prime}$ is the number of compound flood days predicted; $P$ and $S$ represent the precipitation under extreme storm surge, and storm surge under extreme precipitation, respectively; $a$ and $b$ are regression coefficients, and $\varepsilon$ is a constant intercept coefficient. Therefore, the annual number of compound flood days is jointly affected by precipitation and storm surge, and the changes in the number of compound flood days, $\triangle C F^{\prime}$, can be estimated by:

$$
\Delta C F^{\prime}=a \times \Delta P+b \times \Delta S,
$$

where $\Delta P$ and $\Delta S$ are the changes in precipitation under extreme storm surge, and storm surge under extreme precipitation, respectively. The contributions of precipitation under extreme 
storm surge, and storm surge under extreme precipitation to the number of compound flood days can be calculated as:

$$
\left\{\begin{array}{l}
C P=\frac{(a \times \Delta P)}{\Delta C F^{\prime}} \times 100 \% \\
C S=\frac{(b \times \Delta S)}{\Delta C F^{\prime}} \times 100 \%
\end{array}\right.
$$

where $C P$ and $C S$ represent the contributions of precipitation under extreme storm surge, and storm surge under extreme precipitation to the number of compound flood days, respectively. Since the trends of the annual number of compound flood days can be positive or negative, so do the contributions. To facilitate the comparison of contributions of precipitation and storm surge, we transferred the contributions into fractional contributions through:

$$
\left\{\begin{array}{l}
C P^{\prime}=\frac{|C P|}{|C P|+|C S|} \times 100 \% \\
C S^{\prime}=\frac{|C S|}{|C P|+|C S|} \times 100 \%
\end{array}\right.
$$

where $C P^{\prime}$ and $C S^{\prime}$ represent the fractional contributions of precipitation under extreme storm surge, and storm surge under extreme precipitation to the number of compound flood days, respectively.

To reveal the drivers associated with the changes in compound floods, the meteorological variables (i.e., precipitable water content, vertical wind shear, sea level pressure, and near-land wind speed) associated with extreme precipitation and extreme storm surge (i.e., >90th percentiles) in three tide gauges (i.e., New York, NY in the US, Honmoku in Japan, and Tregde in Europe) were analyzed. These three tide gauges were selected based on three criteria: 1) the tide gauges should distribute in different parts of the world for the analysis of spatial variations; 2 ) the tide gauges should have longer data record years for more robust trend analysis; 3 ) the changes in compound flood days are significant at the selected tide gauges, and at least one significant trend can be detected in time series of precipitation and storm surge. For each tide gauge, the precipitable water content and vertical wind shear (calculated as the wind difference between $850 \mathrm{hPa}$ and $200 \mathrm{hPa}$ levels; Chen et al., 2006; Chen et al., 2011; Zhang et al., 2018c) during extreme storm surge events were extracted and averaged by year to examine their relationships with changes in precipitation under extreme storm surge, while sea level pressure and near-land wind speed (i.e., wind speed at the 0.995 sigma level) during extreme precipitation events were extracted and averaged by year to examine their relationships with the changes in storm surge under extreme precipitation. It shall be noted that our analysis on meteorological variables was based on extreme events from 1948 to 2014 because NCEP/NCAR reanalysis dataset is not available before this period. The trends in compound floods between the periods of 1948-2014 and 1979-2014 were analyzed and shown in the Supplementary Material.

The trend of time series was detected using the Modified Mann-Kendall test, which is a nonparametric trend detection method that considers autocorrelation in time series (Hamed and Ramachandra Rao, 1998). A trend was taken as a significant trend when the $p$-value is $<0.1$ (i.e., $a=0.1$ ). Sen's slope method was used to estimate the magnitude of the trend of time series (Sen, 1968).

\section{RESULTS}

\section{Spatial Pattern and Seasonal Variation of Compound Floods}

As shown in Figure 2, we examined the annual number of compound flood days with extreme precipitation and extreme storm surge exceeding the 90th percentiles. In southern Europe, the west and northeast coast of the US, and northern Japan, the compound floods occurred most frequently (i.e., $>12$ per year), followed by the east and southeast of the US, northern Europe, western Australia, and Japan, where experienced average 8-12 compound flood days per year. The co-occurrences of extreme precipitation and storm surge can happen by chance or because of the dependence between univariate extreme events driven by associated meteorological systems. If the precipitation and storm surge are independent of each other, the expected annual number of co-occurrences of precipitation and storm surge exceeding the 90th percentile should be $0.1 \times 0.1 \times 365=3.65$. However, the actual number of compound flood days in reality is affected by various factors such as the dependence between precipitation and storm surge and autocorrelation of time series (Martius et al., 2016). The observed annual number of compound flood days in 305 out of 314 tide gauges was higher than 3.65 , which means that not all compound floods occurred by chance, and the extra compound flood days were very likely to be associated with the dependence between precipitation and storm surge (Zheng et al., 2013; Couasnon et al., 2020). Besides, the dependence between precipitation and storm surge at regional and global scales has been reported in many previous studies (e.g., Zheng et al., 2013; Wahl et al., 2015; Bevacqua et al., 2019; Bevacqua et al., 2020a). For example, Bevacqua et al. (2020a) calculated Kendall's $t$ correlation between precipitation and storm surge and found a stronger correlation between precipitation and storm surge on the coast of the US, western Europe, East Asia, and Australia. This spatial pattern generally coincides with that of the annual number of compound flood days, which further proves the relationship between compound floods and dependence. From these results, the hotspots of compound floods, including the coast of the US, southern Europe, East Asia, and Australia, were identified. The identified hotspots of compound floods are consistent with that of studies that using reanalysis data (Bevacqua et al., 2020a; Couasnon et al., 2020). These areas involve many socioeconomically important regions, such as Europe, the coast of the US, and southeastern China, which hold densely distributed populations and properties and thus exposed to compound flood hazards. When using the 85th and 95th percentiles to identify the compound flood events, or examining the trends between different periods (i.e., 1948-2014 and 1979-2014), the 


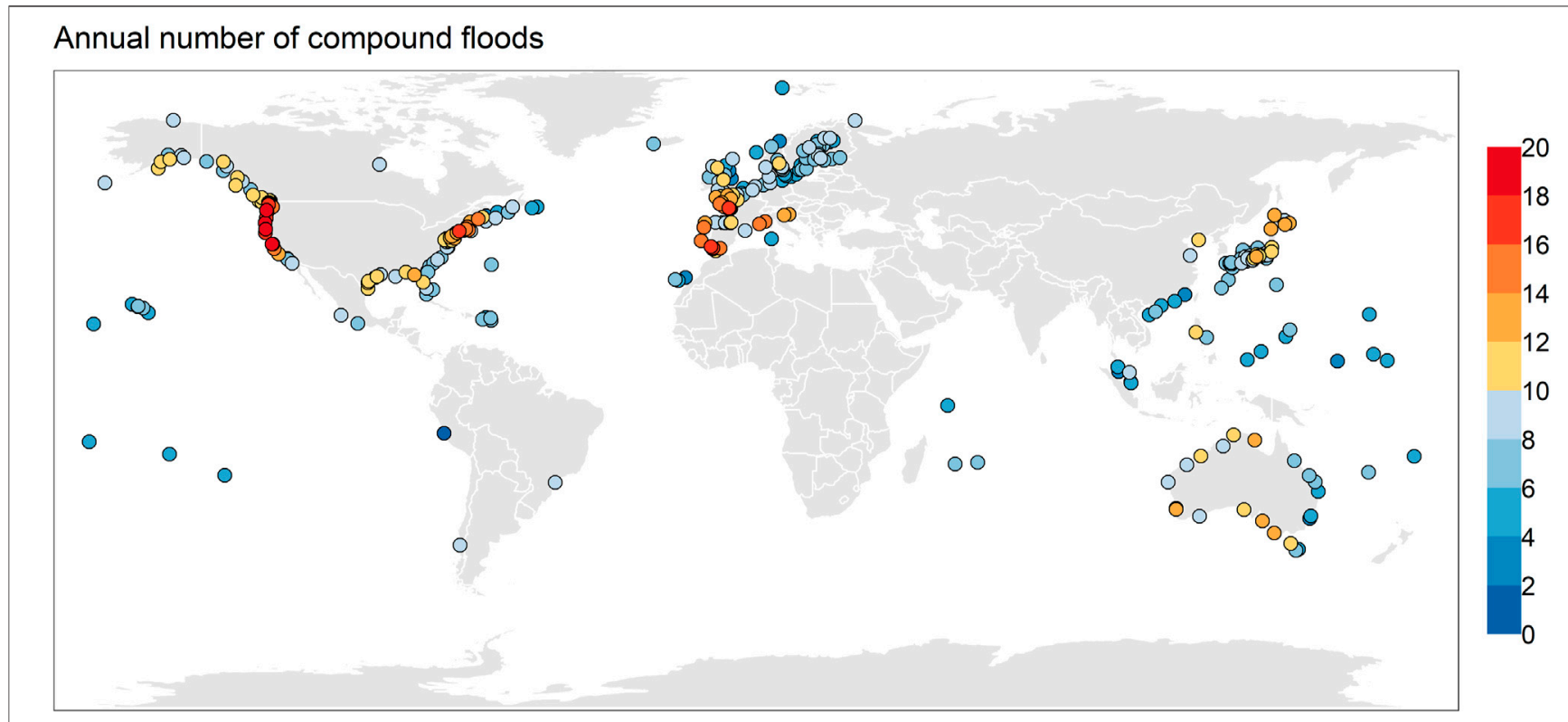

FIGURE 2 | The annual number of compound flood days. Compound flood days are the days with extreme precipitation and extreme storm surge exceeding the 90th percentile values.

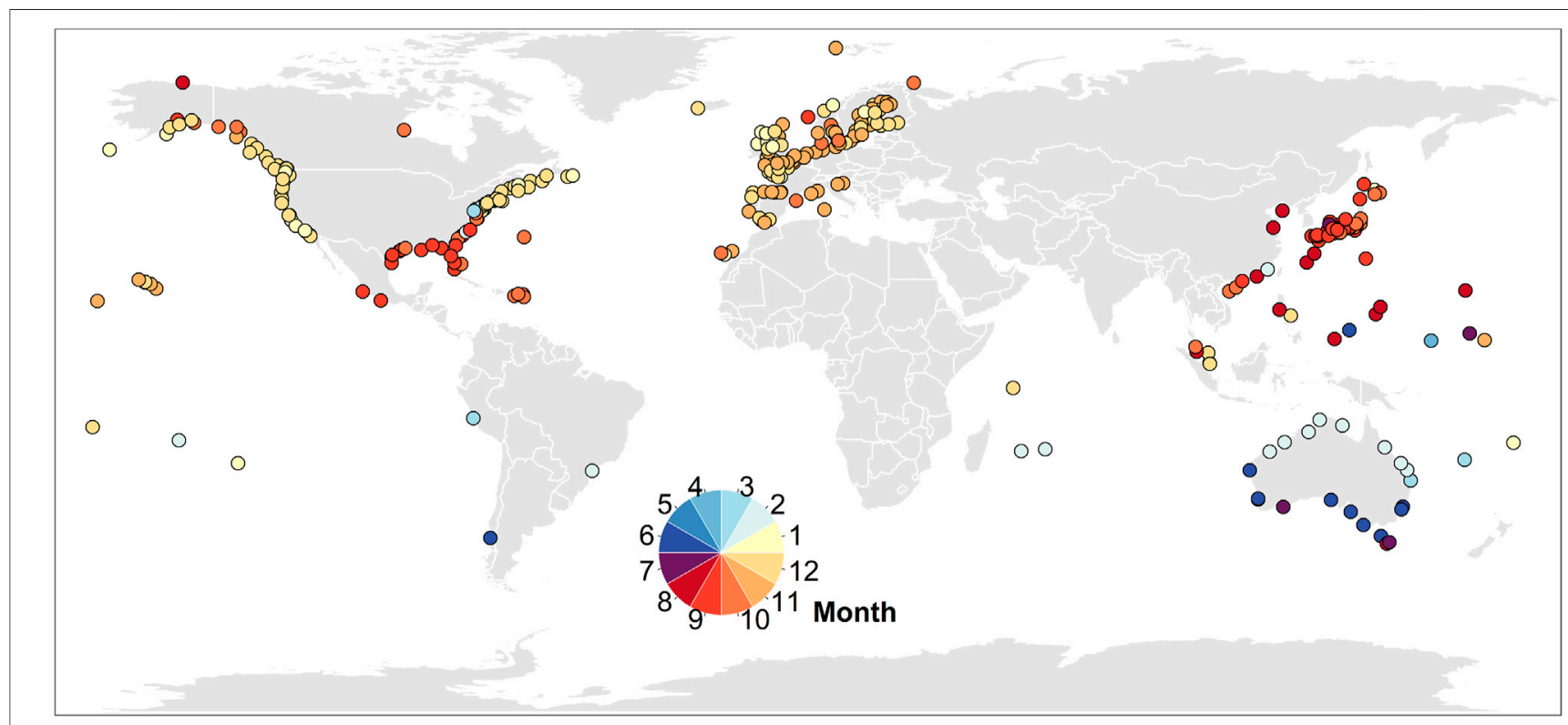

FIGURE 3 | The month with the most frequent concurrences of extreme precipitation and extreme storm surge exceeding the 90th percentile values.

spatial distributions of compound floods showed very similar patterns with those based on the 90th percentile and all available data (Supplementary Figures S1, S5, S8).

Figure 3 shows the months in which compound floods occurred most frequently to illustrate the seasonal variation of compound floods. In Europe, the west coast of North America, and northeast of the US, compound floods tended to occur in November and December, while in the southeast coast of the US, and East Asia, the peak season of compound floods was September. In the Southern Hemisphere, the peak season of compound floods in southern Australia is June, while this was February in northern Australia. In the areas affected by tropical cyclones such as East Asia, the southeast coast of the US, and northern Australia (Walsh et al., 2016; Khouakhi et al., 2017), the occurrences of compound floods were affected by tropical cyclone activities (Wahl et al., 2015; Ikeuchi et al., 2017; 


\section{Trends in number of compound floods}

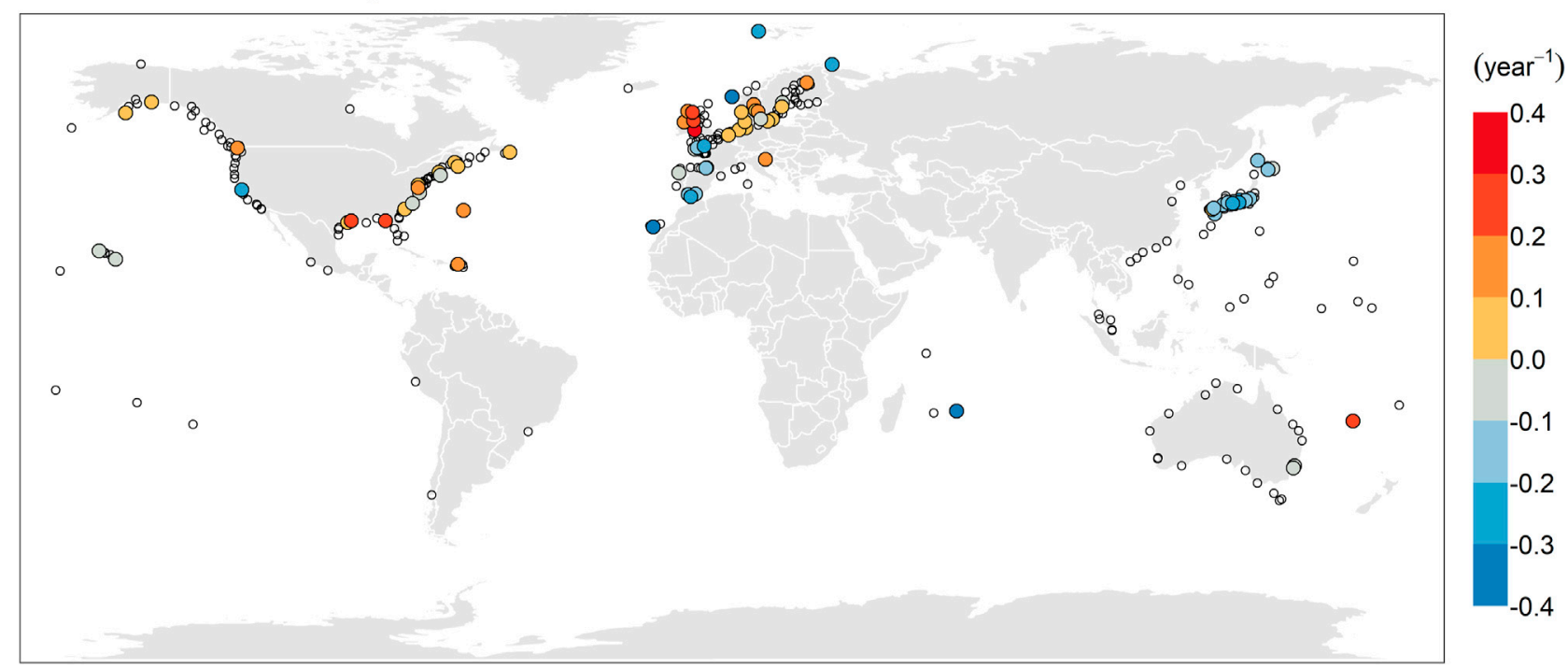

FIGURE 4 | Trends in the annual number of compound flood days. Compound flood days are the days with extreme precipitation and extreme storm surge exceeding the 90th percentile values. Open circles denote the trends are insignificant $(\alpha=0.1)$.

$\mathrm{Xu}$ et al., 2018), and therefore the peak seasons of compound floods were concentrated on tropical cyclone seasons (i.e., July-September in the North Hemisphere, and December-February in the South Hemisphere). In mid and high-latitude areas, the compound floods tended to occur during winter (i.e., November-January in North Hemisphere, and June-July in South Hemisphere).

\section{Trends in Frequency and Intensity of Concurrences of Heavy Precipitation and Storm Surge}

Figure 4 shows the trends in the annual number of compound flood days across the globe. The largest increasing trend was found in the UK, where the number of compound flood days increased by $>2$ days per decade. Besides, in northwestern Europe and the east coast of the US, the annual number of compound flood days increased with a magnitude of 1-3 days per decade, implicating increasing compound flood risks in these areas. In contrast, the number of compound flood days decreased significantly in some tide gauges of southwestern Europe and Japan. The changes in the annual number of compound flood days were not significant (i.e., $p>0.1$ ) in most locations of the east coast of North America, South America, Australia, and Southeast China. Noted that these changes in compound flood days were estimated based on record lengths varying by tide gauge (Figure 1). When constraining the study period as 1948-2014 or 1979-2014, the spatial patterns of changes in compound flood days are similar (Supplementary Figures S6, S9).

To investigate the evolution of the intensity of compound floods, we examined the changes in precipitation under extreme storm surge and the changes in storm surge under extreme precipitation. Figure $\mathbf{5 A}$ shows that precipitation under extreme storm surge increased significantly on the coast of North America, Europe, the east coast of Japan, and some locations of northern Australia, indicating the elevating probability of occurrences of heavy rainfall when extreme storm surges occurred. The changes in storm surge under extreme precipitation showed greater regional variation. On the west and northeast coast of the US and Japan, the storm surge under extreme precipitation decreased slightly (i.e., $<4 \mathrm{~mm} /$ year), while on the southeast coast of the US and Europe, storm surge under extreme precipitation showed an increasing trend (Figure 5B). We examined the sensitivity of these results to the choice of thresholds (i.e., 85th and 95th percentile values. The spatial patterns of changes are consistent with those using the threshold of 90th percentile even though the magnitudes of changes and number of significant trends might be different (Supplementary Figures S2-S4). When conducting these analyses in different periods (i.e., 1948-2014 and 1979-2014), the results are similar except that the storm surge under extreme precipitation showed increasing trends on the northeast coast of the US during 1979-2014, while decreasing trends were detected in this area during the long period (e.g., 1948-2014; Supplementary Figures S7, S10).

Comparing the spatial patterns of changes in compound floods, precipitation under extreme storm surge, and storm surge under extreme precipitation (Figures 4,5), it can be found that, on the west coast of the US where the precipitation increased but the storm surge decreased, the changes in the number of compound flood days were not obvious; in northwestern Europe, both precipitation under extreme storm surge and storm surge under extreme precipitation showed increasing trends, thus the number of compound flood days increased most substantially. In contrast, in Japan, where the precipitation showed different directions in 


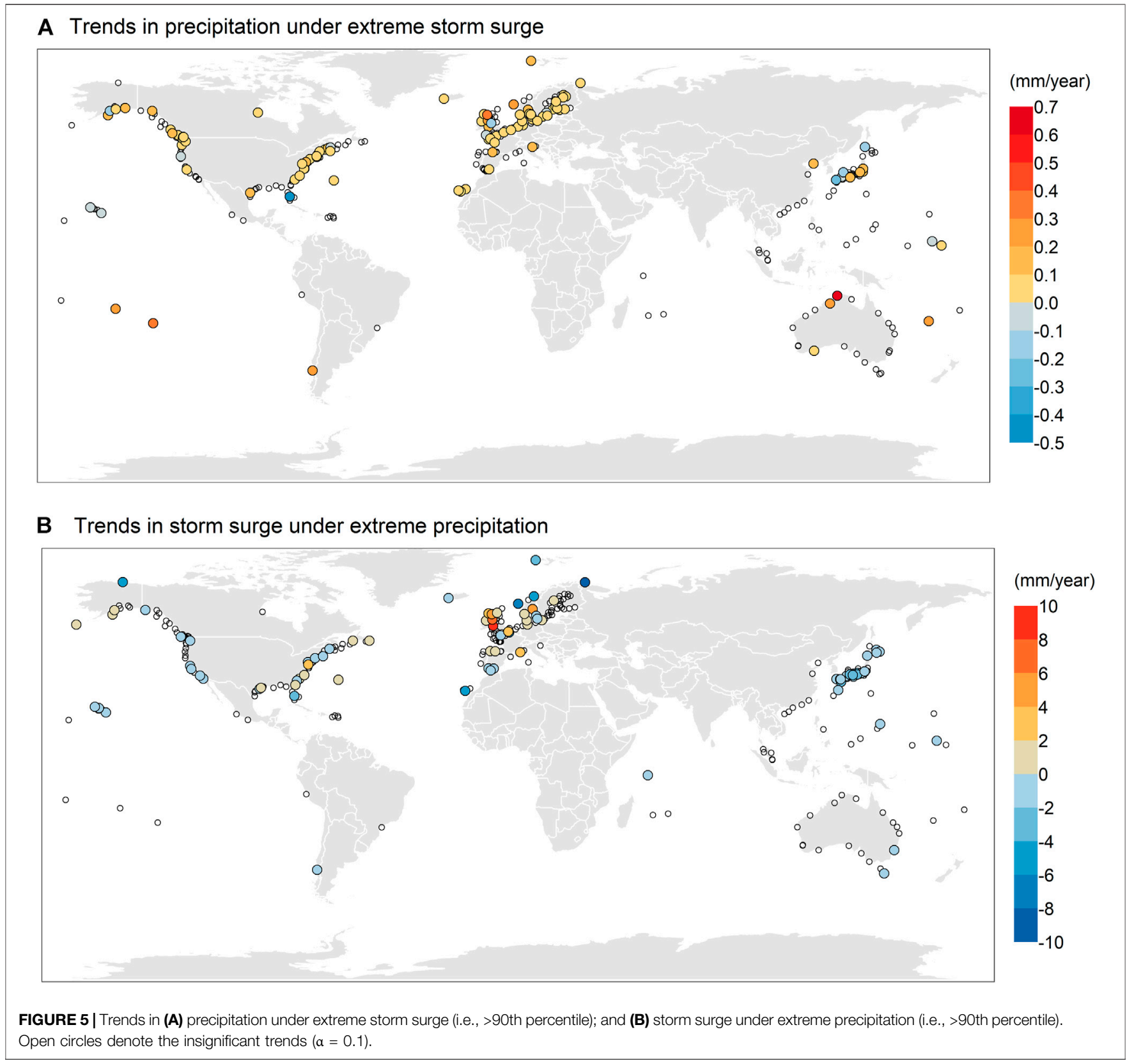

different areas (i.e., negative trends on the west coast and positive trends on the east coast) while the storm surge showed significant decreasing trends across the country, the number of compound flood days also decreased significantly. Comparatively, the spatial distribution of changes in storm surge under extreme precipitation matched better with that of changes in compound floods, implicating that the changes in storm surge were more likely to dominate the changes in compound floods.

To justify this inference, the fractional contributions of precipitation under extreme storm surge, and storm surge under extreme precipitation were calculated based on the multivariate regression methodology. As shown in Figure 6A, the changes in precipitation under extreme storm surge contributed to more than $50 \%$ of changes in compound floods in northern Europe (mainly on the coast of the North Sea and Baltic Sea) and tide gauges on the east coast of the US and southern Australia, indicating the changes in precipitation dominated the changes in compound floods in these areas. By contrast, in the other areas including the west coast of the US, western and southern Europe, Japan, northern Australia, and also some tide gauge on the east coast of the US, the fractional contribution of changes in storm surge under extreme precipitation exceeded $50 \%$, demonstrating the dominate role of storm surge in affecting the number of compound flood days (Figure 6B). The average contributions of precipitation and storm surge across the globe were 35 and 65\%, respectively. 


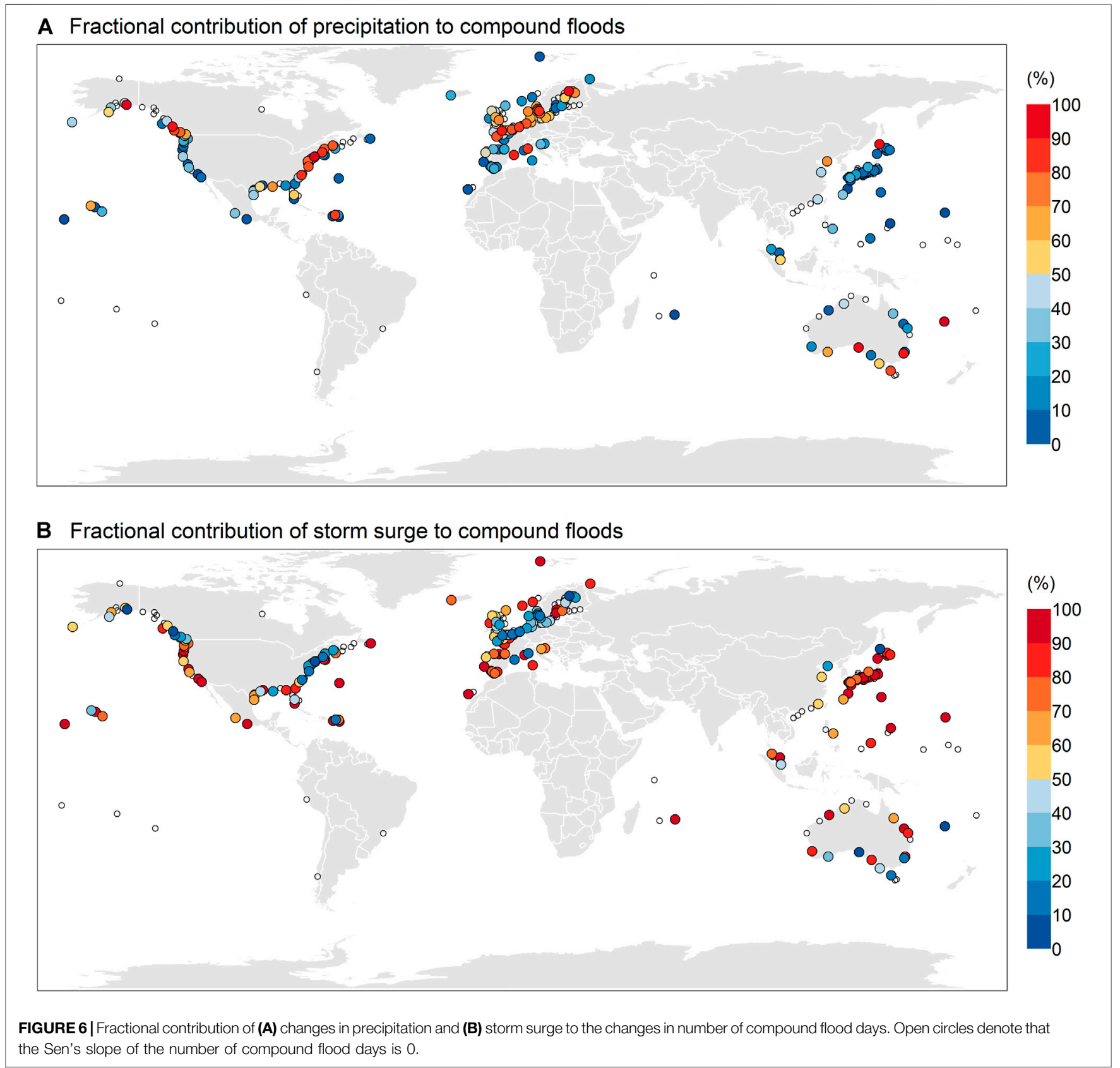

These results further prove our inference that changes in storm surge were more likely to dominate the changes in compound floods.

\section{Changes in Meteorological Variables Associated With Precipitation Under Extreme Storm Surge and Storm Surge Under Extreme Precipitation}

The meteorological variables including precipitable water content, vertical wind shear, sea level pressure, and near-land wind speed associated with extreme precipitation and extreme storm surge (i.e., $>90$ th percentiles) in three tide gauges (i.e., New
York, NY, Honmoku, and Tregde) were analyzed to explore the meteorological drivers associated with changes in the compound floods. Before evaluating the changes in meteorological variables, the time series of the annual number of compound flood days, precipitation under extreme storm surge, and storm surge under extreme precipitation in tide gauges New York, NY, Honmoku, and Tregde were analyzed for more details (Figures 7, 8). In New York, NY, the annual number of compound flood days showed an insignificant increasing trend during the long period between 1921 and 2014, while the significant slight increasing trend was detected in the shorter period between 1948 and 2014 (Figure 7A). In Honmoku, the number of compound flood days significantly decreased by $40 \%$ during 1961-2006 


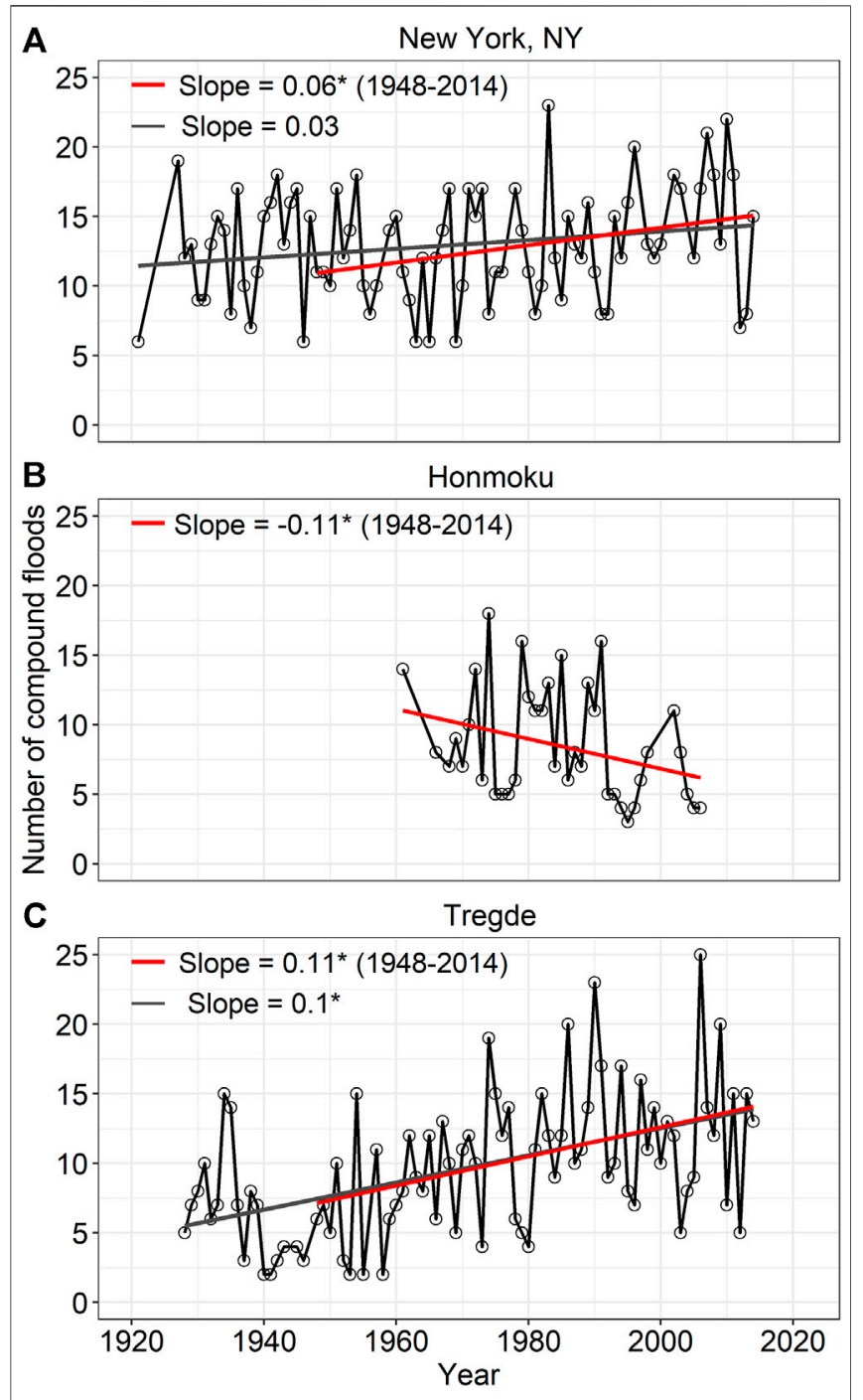

FIGURE 7 | Temporal evolution of the annual number of compound flood days in tide gauge (A) New York, NY, (B) Honmoku, and (C) Tregde. The black straight line in $(\mathbf{A})$ and $(\mathbf{C})$ indicates the trend of the complete time series. The red straight line indicates the trend of the time series during 1948-2014. The Sen's slopes were estimated. Significant trends are identified by an asterisk $(\alpha=0.1)$.

(Figure 7B). In contrast, the number of compound flood days increased by $153 \%$ during 1928-2014 in Tregde, and this percentage is $97 \%$ for the shorter period from 1948 to 2014 (Figure 7C). The results of changes in the number of compound flood days were also supported by the changes in precipitation under extreme storm surge and storm surge under extreme precipitation. In New York, NY, the precipitation under extreme storm surge increased significantly in both longer and shorter periods, which contributed to more than $90 \%$ of the changes in the number of compound flood days (Table 1). The storm surge under extreme precipitation showed no obvious trend and contributed less to the increase of compound floods (Figures 8A,B). In Honmoku, the changes in precipitation under extreme storm surge were not significant, but the storm surge under extreme precipitation decreased by $26 \%$, which was responsible for the increase in the number of compound flood days (Figures 8C,D; Table 1). For the tide gauge Tregde, both precipitation under extreme storm surge and storm surge under extreme precipitation showed significant increasing trends (Figures 8E,F), indicating more intense precipitation when extreme storm surge events occurred, and higher storm surge during extreme precipitation events. The fractional contributions of precipitation and storm surge in Tregde are 62.7 and $37.3 \%$, respectively (Table $\mathbf{1}$ ).

The changes in precipitable water content and vertical wind shear on the days of extreme storm surge were estimated to investigate their relationships with changes in precipitation under extreme storm surge. The precipitable water content measures the amount of available moisture in the atmosphere, which is closely related to precipitation (Dong et al., 2019; Kunkel et al., 2020). Vertical wind shear measures the changes of winds with height, which relates to convective activity (Tramblay et al., 2020). Vertical wind shear has different impacts on different types of storms: an environment of weak vertical wind shear favors the genesis and maintenance of tropical cyclones (Frank and Ritchie, 2001; Wong and Chan, 2004), while significant vertical wind shear is required for the development of extratropical cyclones (Lim and Simmonds, 2007; Ynase and Niino, 2015; Ynase and Niino, 2019). In New York, NY, the precipitable water content around the New York showed an insignificant trend, while the vertical wind shear was stronger at the north of New York, NY, and weaker in the south of New York, NY (Figures 9A,D). The weaker vertical wind shear over the sea to the southeast of New York, NY allowed the tropical cyclones to sustain for a longer duration and move to the midlatitudes, and the increased vertical wind shear at higher latitude areas is likely a signature of the extratropical transition processes of tropical cyclones (Liu et al., 2017; Towey et al., 2018; Evans and Hart, 2003). The more frequent cyclone activities imply more precipitation events, which is consistent with the observed increasing trend of precipitation under extreme storm surge during the period from 1948 to 2014 in New York, NY. In Honmoku, the precipitable water content decreased significantly, which was consistent with the decreasing trend of precipitation under extreme storm surge (Figure 9B). The vertical wind shear showed an increasing but insignificant trend (Figure 9E). Considering that Honmoku is frequently affected by tropical cyclones (e.g., tropical cyclones contribute to $40-65 \%$ of extreme precipitation in Japan; Khouakhi et al., 2017), the increased vertical wind shear might apply an adverse impact on the strength maintenance of tropical cyclones and cause a shorter duration of tropical cyclones over this region. In Tregde, the changes in precipitable water content were insignificant, while the vertical wind shear showed increasing trends over most of western Europe, implicating the enhanced convective activity in this region (Figures 9C,F). Furthermore, the increased vertical wind shear in higher latitude might contribute to the development of extratropical cyclones, which is an important driver of heavy rainfall and extreme storm surge in Europe (Hawcroft et al., 2012; Hawcroft et al., 2018; Weisse et al., 2012; Pinto et al., 2014). In this case, the increase in 

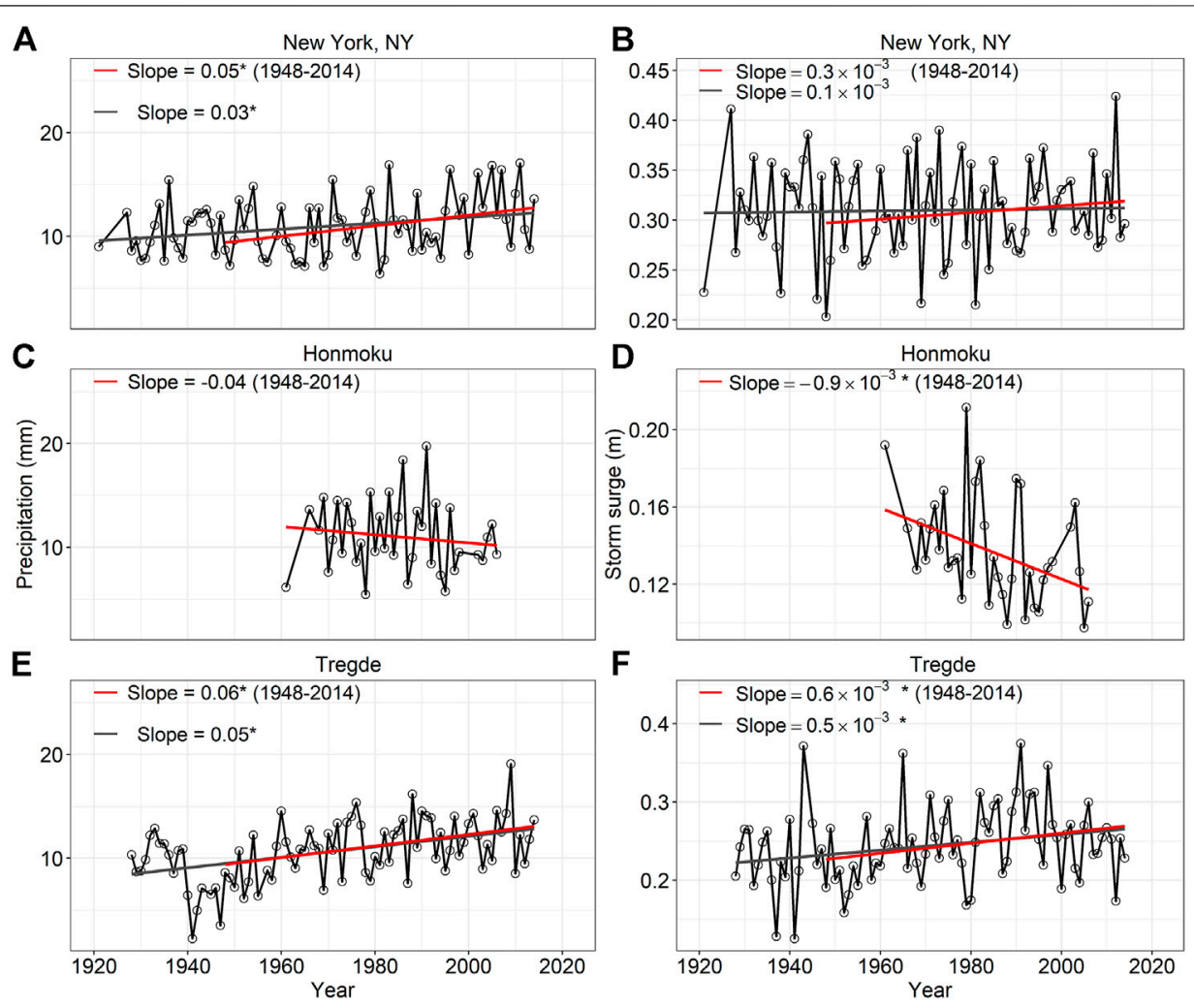

FIGURE 8| Temporal evolution of (A, C, E) precipitation under extreme storm surge, and (B, D, F) storm surge under extreme precipitation in tide gauge (A, B) New York, NY (C, D) Honmoku, and (E, F) Tregde. The black straight line in (A) and (C) indicates the trend of the complete time series. The red straight line indicates the trend of the time series during 1948-2014. The Sen's slopes were estimated. Significant trends were identified by an asterisk $(\alpha=0.1)$.

TABLE 1 | Statistics of compound floods, precipitation and storm surge between 1948 and 2014.

\section{Tide gauge}

Trends of compound flood days (year $\left.{ }^{-1}\right)$

Trends of precipitation ( $\mathrm{mm} / \mathrm{year}$ )

Trends of storm surge $\left(10^{-3} \mathrm{~m} / \mathrm{year}\right)$

Contribution of precipitation (\%)

Contribution of storm surge (\%)

\begin{tabular}{c} 
New York, N \\
\hline $0.06^{\star}$ \\
$0.05^{\star}$ \\
0.3 \\
94.8 \\
5.2
\end{tabular}

The asterisks (*) denote significant trends $(\alpha=0.1)$.

precipitation under extreme storm surge might be related to the increase of vertical wind shear.

The sea level pressure and near-land wind speed on the days of extreme precipitation were analyzed to examine their relationships with storm surge under extreme precipitation. Results showed that the changes in sea level pressure around the New York, NY were not significant (Figure 10A), while the wind over the waterside of New York, NY increased significantly, which can cause higher wind waves (Figure 10D). In Honmoku, the sea level pressure increased over large areas of the Western North Pacific (Figure 10B). The increasing trend over large areas helps little in increasing the pressure gradient, thus may not help increase the storm surge. What's more, the winds were weaker over the near-coast sea area, which is unfavorable for the generation of wind waves (Figure 10E). In Tregde, the sea level pressure decreased over the north of the location of interest, but increased over the other side (Figure 10C). This change increased the pressure gradient, resulting in higher storm surges. At the same time, the significant intensifying winds over western Europe also contributed to the increase of wind waves under extreme precipitation (Figure 10F).

\section{DISCUSSIONS}

In this study, we analyzed the evolution of precipitation under extreme storm surge and storm surge under extreme precipitation to attribute the changes in compound floods. According to the 


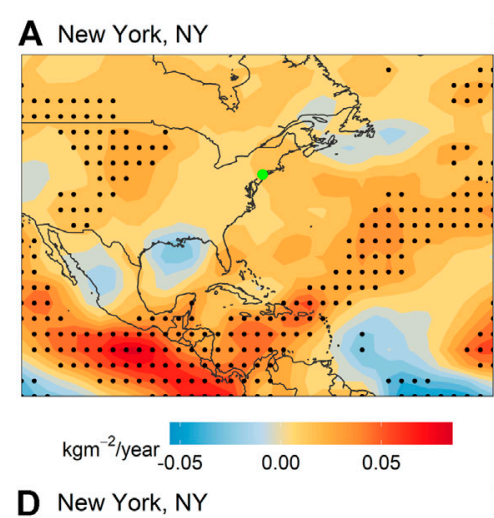

\section{B Honmoku}

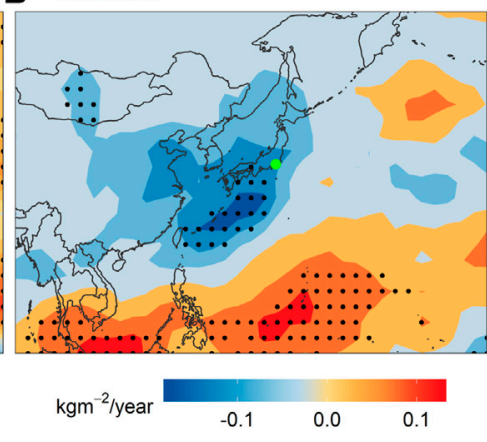

E

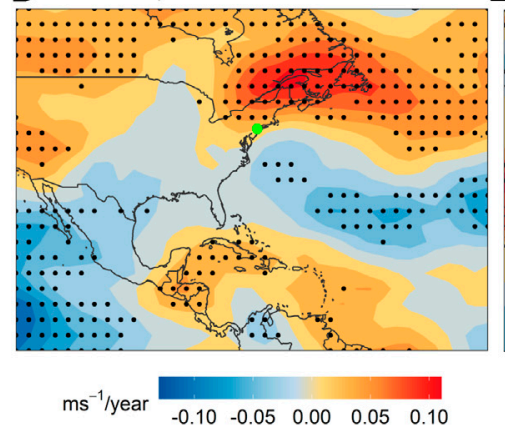

E Honmoku

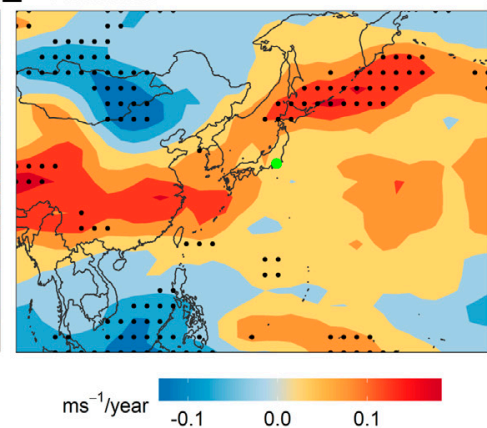

C Tregde

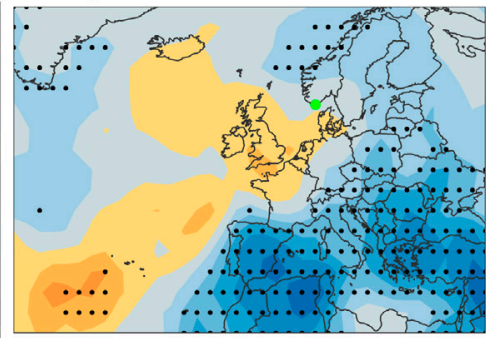

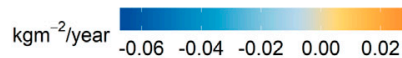

F Tregde

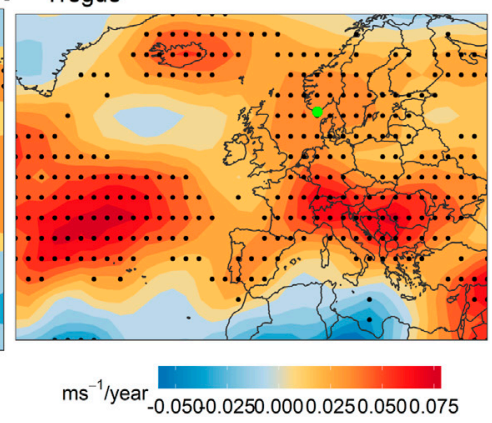

FIGURE 9 | Trends in (A-C) precipitable water contents $\left(\mathrm{kgm}^{-2} /\right.$ year) and (D-F) vertical wind shear $\left(\mathrm{ms}^{-1} /\right.$ year) during precipitation under extreme storm surge in tide gauge New York, NY (A, D), Honmoku (B, E), and Tregde (C, F). Locations of the tide gauges interested are denoted by the green spots. Stippled regions represent areas with significant trends $(\alpha=0.1)$.

definitions provided in Intergovernmental Panel on Climate Change, 2012, compound events can be two or more extreme events occurring simultaneously (i.e., compound floods defined in this study), and the combinations of events, that alone are not extreme, leading to an extreme impact. For floods events, the compound floods can be combinations of 1) extreme precipitation and extreme storm surge (i.e., compound floods defined in this study), 2) extreme storm surge and precipitation that can produce runoff and thus increase water level at the estuary, and 3) extreme precipitation and storm surge that may be not extreme but great enough to block or slow down the drainage (Wahl et al., 2015; Zscheischler et al., 2018). In this case, the precipitation under extreme storm surge contains the second type of compound flood events, and the third type of compound floods was included in the storm surge under extreme precipitation. The increasing trends in precipitation under extreme storm surge across the worlds can be interpreted in two aspects: 1) As the precipitation increasing, the probability of concurrence of extreme precipitation and extreme storm surge is higher than before (i.e., more precipitation under extreme storm surge reaches extreme levels). 2) Given an extreme storm surge event, the precipitation is more intense (not has to be extreme), therefore its interplay with storm surge is more probable to exacerbate the adverse impact. This interpretation also applies to storm surge under extreme precipitation. From this perspective, analyzing the precipitation under extreme storm surge and storm surge under extreme precipitation could provide more information than analyzing the precipitation and storm surge directly.

Even though compound floods are receiving more and more attention, rare studies have analyzed the inter-annual changes in compound floods during past decades based on observational data. At the regional scale, Wahl et al. (2015) examined the enhanced dependence between precipitation and storm surge, and reported the increasing trends in compound flood risk in past decades along the coast of the US. At the global scale, our study analyzed the trends in compound floods, precipitation under extreme storm surge, and storm surge under extreme precipitation based on observations, and found the significant increasing trends in compound flood risk over Europe and the US in past decades. These findings are critical to better understand the changing compound flood risk, and provide important references for the evaluation of the simulation-based studies. For example, Bevacqua et al. (2019), Bevacqua et al. (2020b) projected the higher probability of occurrence of compound floods from precipitation and storm surge across the globe under a high emission scenario in the future, which means the increasing trends identified in this study are probable to continue in the future. However, in Japan, where the compound floods and storm surge under extreme precipitation decreased significantly from 1961 to 2006, the return periods of compound floods were projected to shorten by $>60 \%$ under a high emissions scenario (Bevacqua et al., 2020b). The mechanisms behind this transition from the downward trend in the past to the upward trend in the 

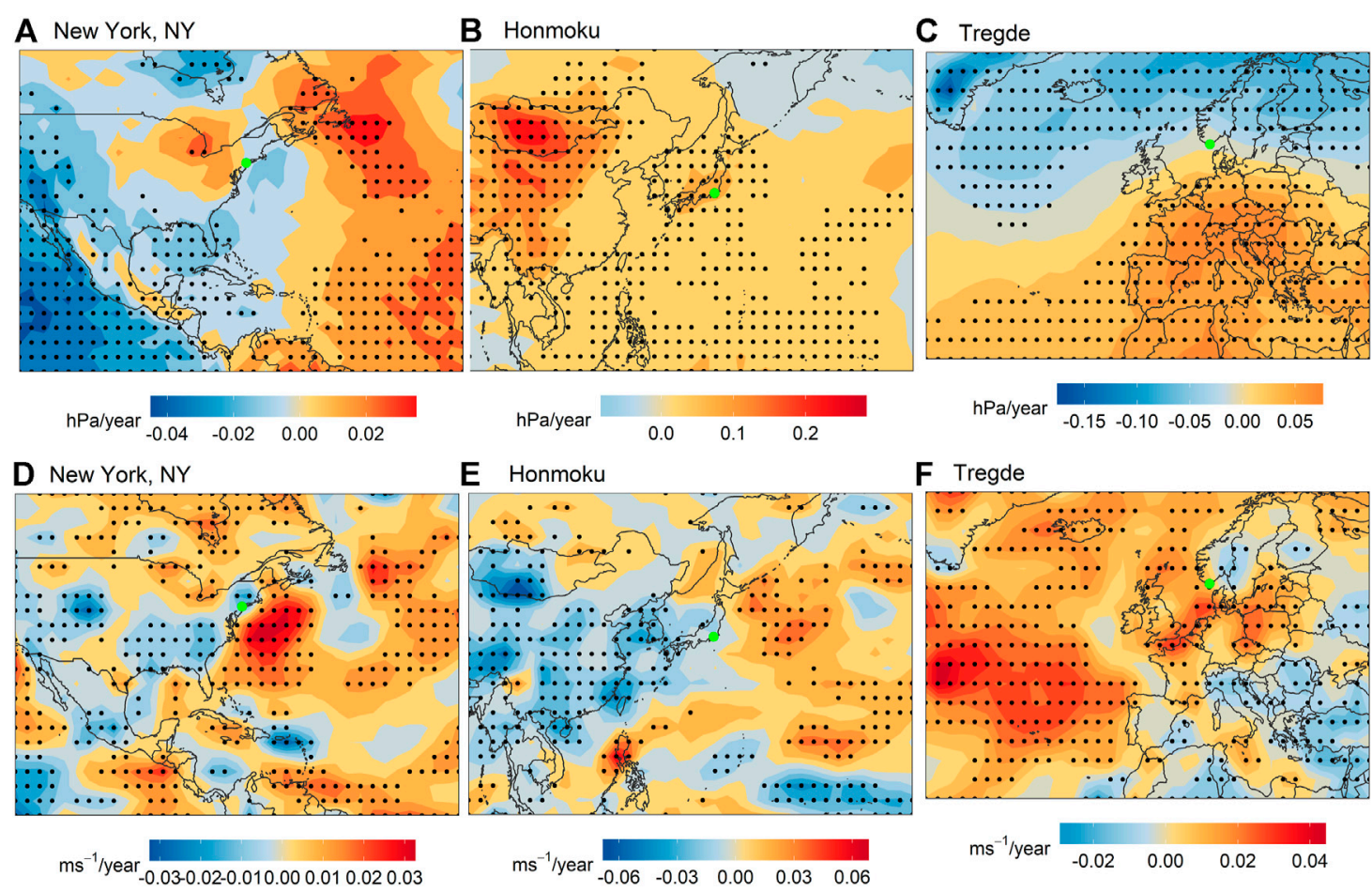

FIGURE 10 | Trends in (A-C) sea level pressure (hPa/year) and (D-F) wind speed ( $\mathrm{ms}^{-1}$ /year) during storm surge under extreme precipitation in tide gauge New York, NY (A, D), Honmoku (B, E), and Tregde (C, F). Locations of the tide gauges interested are denoted by the green spots. Stippled regions represent areas with significant trends $(\alpha=0.1)$.

future are worth exploring. Considering the relatively short record lengths of observational data in this region and the large uncertainties of simulation-based studies, further studies are needed to examine the characteristics of compound flood events in Japan.

The results of compound floods from heavy precipitation and extreme storm surge exceeding the 90th percentiles were discussed in this study. The compound floods exceeding the 85th percentiles and 95th percentiles were analyzed and were shown in the SI (Supplementary Figures S1-S4). Compared the changes in the annual number of compound flood days of different intensities, we found that the direction of trends (i.e., increase or decrease) was consistent between compound floods of different intensities, but the lower the threshold, the more stations showing significant trends (Figure $\mathbf{4}$ and Supplementary Figure S2). This phenomenon could also be found in the changes in precipitation under extreme precipitation (Figure 5A and Supplementary Figure S3). For storm surge under extreme precipitation, the spatial pattern of changes in storm surge under extreme precipitation exceeding the 85th percentiles was almost the same as that of exceeding the 90th percentiles. However, the changes in storm surge under extreme precipitation turned from negative to positive in some stations on the coast of the US when the thresholds elevated from 85th to 95th percentiles (Figure 5B and Supplementary Figure S4), indicating the higher storm surge occurred during the most extreme precipitation events. In general, the spatial patterns of changes in compound floods, precipitation under extreme storm surge, and storm surge under extreme precipitation defined by 85th and 95th percentiles were very similar, except that when using the higher threshold (i.e., the 95th percentile), less significant trends could be detected because less extreme events could be identified when using the higher threshold. However, if the threshold is set too low, there is a risk of failing in capturing the change signal of the most extreme event. Results of the sensitivity analyses show that the spatial and temporal characteristics of compound floods are similar when using the inverse distance weighted method to calculate the average precipitation (Supplementary Figures S11-S13).

Previous studies found that the weather conditions associated with compound floods were characterized by the deep lowpressure system, cyclonic winds, and high precipitable water contents (Wahl et al., 2015; Bevacqua et al., 2019). We also analyzed these meteorological variables to explain the changes in precipitation under extreme storm surge and storm surge under extreme precipitation. Results found that the changes in storm surge under precipitation in three locations (i.e., New York, NY, Honmoku, and Tregde) could be well explained by the changes in sea level pressure and near-land wind speed. The physical mechanisms that impact the precipitation under extreme storm surge might be more complex. The changes in precipitable water content could not explain all the changes in precipitation under extreme storm surge. For example, in Tregde, the precipitable water content showed no significant trends, while 
the precipitation under extreme storm surge here increased significantly by $51 \%$. Therefore, there might be some other factors causing the increase in precipitation. We further analyzed the vertical wind shear. Results showed that the increased vertical wind shear might reflect the enhanced convective activity in Europe, which might be related to the increased precipitation under extreme storm surge. But the impact of vertical wind shear should be identified carefully because of its complex effect on storms. Storms such as tropical cyclones and extratropical cyclones are accompanied by low-pressure, cyclonic wind, and abundant moisture transportation, and thus usually cause compound floods. Further studies focused on the impact of storm activities on compound floods will be helpful to better understand the characteristics of compound floods.

In this study, we used the non-tidal residual to represent the meteorologically driven coastal flood without consideration of the storm-tide interaction, which might cause uncertainties in the results. Many studies have pointed out that the storm-tide interaction can not be neglected when estimating the extreme sea levels, because the storm-tide interaction could modulate the actual highest water level (Horsburgh and Wilson, 2007; Zhang et al., 2010; Mawdsley and Haigh, 2016; Williams et al., 2016; Arns et al., 2020). When neglecting the storm-tide interaction, the storm surge was assumed to be independent of the water level, which is not true because the observed highest storm surge was found to be more likely to occur at mid- or low-tides rather than at the high-tides (Horsburgh and Wilson, 2007). If neglecting the non-linear storm-tide interaction, the extreme sea level would be overestimated by 30\% (Arns et al., 2020). However, since the storm-tide interaction is highly affected by local features such as locations, topography, oscillations, tide ranges, etc., it shows less robust correlation with tidal levels or tidal contributions and varies greatly across different regions of the world (Zhang et al., 2010; Arns et al., 2020). In general, it has been identified that the storm-tide interaction is strongest on the east coast of the US, western Europe, northern Australia, and Japan (Mawdsley and Haigh, 2016; Arns et al., 2020). Even though we are aware of the important role of storm-tidal interaction in modulating the estimation of coastal floods, it is still uncertain that what method can be used to take care of storm-tide interaction efficiently when assessing the coastal flood. Some previous studies have tried to use skew surge, which is the difference between the maximum total water level and maximum predicted tidal level within a tidal cycle, to represent the coastal floods, and suggested the independence between skew surge and tide (Mawdsley and Haigh, 2016; Williams et al., 2016). However, a more recent statistical method-based study assessed the nonlinear storm-tide interaction and found that both non-tidal residuals and skew surges associated with the highest water levels were significantly dependent on tide (Arns et al., 2020). Besides, since the skew surge is an integrated measure calculated within tidal cycles, it runs the risk of losing information of changes in water levels driven by meteorological factors (Mawdsley and Haigh, 2016; Williams et al., 2016). For example, Mawdsley and Haigh (2016) mentioned that the skew surge failed in capturing extreme storm surge caused by tropical cyclones. Therefore, we studied the compound floods based on the traditional non-tidal residual in this study. Although the uncertainties remain, we would like to highlight the contribution of our results on revealing the evolutions of compound floods potential from heavy precipitation and storm surge driven by meteorological systems based on historical observations.

\section{CONCLUSION}

In this study, the spatial and temporal characteristics of concurrences of precipitation and storm surge were examined based on observed storm surge and precipitation with the longest overlapping record of $>120$ years. First, the spatial distribution and seasonal variation of concurrent extreme precipitation and storm surge were presented. Then the trends in compound floods, precipitation under extreme storm surge, and storm surge under extreme precipitation were estimated to illustrate the long-term changes in compound floods. Last, the changes in weather conditions associated with precipitation under extreme storm surge, and storm surge under extreme precipitation in three tide gauges were analyzed to investigate the possible mechanisms associated with the changes in compound floods. Our main findings include:

1) The areas including southern Europe, the west and northeast coast of the US, and northern Japan experienced $>12$ compound flood days per year, followed by the east and southeast of the US, northern Europe, western Australia, and Japan, where experienced average of 8-12 compound flood days per year. The seasonal variation analysis showed that in the south and east coast of the US, the north of South America, East Asia, and northern Australia, most of the compound floods occurred during tropical cyclones seasons (i.e., July-September in North Hemisphere and December-February in South Hemisphere), while in mid and high-latitude areas (i.e., the north of North America, Europe, the south of South America and southern Australia), most occurrences of compound floods concentrated on the winter (i.e., November-January in North Hemisphere and June-August in South Hemisphere).

2) Our results on evolutions of frequency of compound flood days showed an increasing trend in compound flood risk in most areas across the globe except Japan. Europe experienced the most substantial increase in compound flood days (i.e., increased by $>2$ days per decade), followed by the east coast of the US (i.e., increased by 1-3 days per decade). Increased precipitation under extreme storm surge could be identified in North America, Europe, and Australia, indicating more intense precipitation under extreme storm surge events. The changes in storm surge under extreme precipitation showed larger regional variation. The significant increasing trends could be found in Europe, the east coast of the US, while decrease trends were mainly found in Japan and the west coast of the US. This result was consistent with the changes in the annual number of 
compound flood days. The contribution analysis indicated that except in northern Europe and some tide gauges on the east coast of the US and southern Australia, the fractional contribution of storm surge on the changes in the number of compound flood days exceeded 50\% in most areas across the globe, which demonstrated that the changes in storm surge were more likely to dominate the changes in compound floods.

3) The analyses on meteorological variables suggested that the changes in storm surge under extreme precipitation were likely driven by changes in sea level pressure and near-land winds, while the changes in precipitation under extreme storm surge were associated with the changes in precipitable water content and the convective activity.

This study presented the spatial distribution and seasonal variation of compound floods from precipitation and storm surge, estimated the changes in compound floods, precipitation under extreme storm surge, and storm surge under extreme precipitation across the globe. These analyses were based on the observed precipitation and storm surge data with the longest record lengths of 126 years, which can provide useful information for better understanding the evolution in compound floods, and serve as scientific references in flood risk management and climate change adaptation strategy design.

\section{DATA AVAILABILITY STATEMENT}

Publicly available datasets were analyzed in this study. This data can be found here: The daily precipitation data from Global

\section{REFERENCES}

Arns, A., Wahl, T., Wolff, C., Vafeidis, A. T., Haigh, I. D., Woodworth, P., et al. (2020). Non-linear Interaction Modulates Global Extreme Sea Levels, Coastal Flood Exposure, and Impacts. Nat. Commun. 11 (1), 1-9. doi:10.1038/s41467020-15752-5

Bevacqua, E., Maraun, D., Hobæk Haff, I., Widmann, M., and Vrac, M. (2017). Multivariate Statistical Modelling of Compound Events via Pair-Copula Constructions: Analysis of Floods in Ravenna (Italy). Hydrol. Earth Syst. Sci. 21 (6), 2701-2723. doi:10.5194/hess-21-2701-2017

Bevacqua, E., Maraun, D., Vousdoukas, M. I., Voukouvalas, E., Vrac, M., Mentaschi, L., et al. (2019). Higher Probability of Compound Flooding from Precipitation and Storm Surge in Europe under Anthropogenic Climate Change. Sci. Adv. 5 (9), 5531. doi:10.1126/sciadv.aaw5531

Bevacqua, E., Vousdoukas, M. I., Shepherd, T. G., and Vrac, M. (2020a). Brief Communication: The Role of Using Precipitation or River Discharge Data when Assessing Global Coastal Compound Flooding. Nat. Hazards Earth Syst. Sci. 20 (6), 1765-1782. doi:10.5194/nhess-20-1765-2020

Bevacqua, E., Vousdoukas, M. I., Zappa, G., Hodges, K., Shepherd, T. G., Maraun, D., et al. (2020b). More Meteorological Events that Drive Compound Coastal Flooding Are Projected under Climate Change. Commun. Earth Environ. 1 (1). doi:10.1038/s43247-020-00044-z

Booth, J. F., Rieder, H. E., and Kushnir, Y. (2016). Comparing hurricane and Extratropical Storm Surge for the Mid-Atlantic and Northeast Coast of the United States for 19792013. Environ. Res. Lett. 11 (9). doi:10.1088/1748-9326/11/9/094004

Intergovernmental Panel on Climate Change (2012). "Changes in Climate Extremes and Their Impacts on the Natural Physical Environment," in Managing the Risks of Extreme Events and Disasters to Advance Climate Change Adaptation. C. B. Field,
Historical Climatology Network (GHCN-Daily) is available at https:/www.ncdc.noaa.gov/ghcn-daily-description. The hourly sea level from the Global Extreme Sea Level Analysis version 2 (GESLA-2) can be obtained from https://www.gesla.org/. The NCEP/NCAR reanalysis dataset can be obtained from https://psl. noaa.gov/data/gridded/data.ncep.reanalysis.html.

\section{AUTHOR CONTRIBUTIONS}

QL, JL, and YL designed study; YL and JL performed research; YL, QL, JL, QZ, XZ, GW analyzed and wrote the paper.

\section{FUNDING}

The work described in this paper was supported by grants from the National Key R\&D Program of China (Project No. 2019YFC1510400), Natural Science Foundation of China (NSFC) General Program (41971386), the Research Grants Council of the Hong Kong Special Administrative Region, China (HKBU12303517, HKBU12302518, and 12301820), and Guangdong-Hong Kong Joint Laboratory for Water Security (2020B1212030005).

\section{SUPPLEMENTARY MATERIAL}

The Supplementary Material for this article can be found online at: https://www.frontiersin.org/articles/10.3389/feart.2021.660359/ full\#supplementary-material

V. Barros, T. F. Stocker, D. Qin, D. Jon Dokken, K. L. Ebi, et al. (Cambridge, UK, and New York, NY, USA: Cambridge University Press), 109-230.

Chan, F. K. S., Mitchell, G., Adekola, O., and McDonald, A. (2012). Flood Risk in Asia's Urban Mega-Deltas. Environ. Urbanization Asia 3 (1), 41-61. doi:10.1177/097542531200300103

Couasnon, A., Eilander, D., Muis, S., Veldkamp, T. I. E., Haigh, I. D., Wahl, T., et al. (2020). Measuring Compound Flood Potential from River Discharge and Storm Surge Extremes at the Global Scale. Nat. Hazards Earth Syst. Sci. 20 (2), 489-504. doi:10.5194/nhess-20-489-2020

Dong, S., Sun, Y., Li, C., Zhang, X., Min, S.-K., and Kim, Y.-H. (2021). Attribution of Extreme Precipitation with Updated Observations and CMIP6 Simulations. J. Clim. 34 (3), 871-881. doi:10.1175/jcli-d-19-1017.1

Dong, W., Lin, Y., Wright, J. S., Xie, Y., Yin, X., and Guo, J. (2019). Precipitable Water and CAPE Dependence of Rainfall Intensities in China. Clim. Dyn. 52 (5-6), 3357-3368. doi:10.1007/s00382-018-4327-8

Emanuel, K. (2017). Assessing the Present and Future Probability of Hurricane Harvey's Rainfall. Proc. Natl. Acad. Sci. USA 114 (48), 12681-12684. doi:10.1073/pnas.1716222114

Evans, J. L., and Hart, R. E. (2003). Objective Indicators of the Life Cycle Evolution of Extratropical Transition for Atlantic Tropical Cyclones. Mon. Wea. Rev. 131 (5), 909-925. doi:10.1175/1520-0493(2003)131<0909:oiotlc $>2.0$.co;2

Fatichi, S., and Caporali, E. (2009). A Comprehensive Analysis of Changes in Precipitation Regime in Tuscany. Int. J. Climatol. 29 (13), 1883-1893. doi:10.1002/joc.1921

Frank, W. M., and Ritchie, E. A. (2001). Effects of Vertical Wind Shear on the Intensity and Structure of Numerically Simulated Hurricanes. Mon. Wea. Rev. 129 (9), 2249-2269. doi:10.1175/1520-0493(2001)129<2249:eovwso >2.0.co;2

Gemmer, M., Fischer, T., Jiang, T., Su, B., and Liu, L. L. (2011). Trends in Precipitation Extremes in the Zhujiang River basin, South China. J. Clim. 24 (3), 750-761. doi:10.1175/2010jcli3717.1 
Gori, A., Lin, N., and Xi, D. (2020). Tropical Cyclone Compound Flood Hazard Assessment: From Investigating Drivers to Quantifying Extreme Water Levels. Earth's Future 8 (12). doi:10.1029/2020ef001660

Gu, X., Zhang, Q., Singh, V. P., and Shi, P. (2017). Nonstationarity in Timing of Extreme Precipitation across China and Impact of Tropical Cyclones. Glob. Planet. Change 149, 153-165. doi:10.1016/j.gloplacha.2016.12.019

Hamed, K. H., and Ramachandra Rao, A. (1998). A Modified Mann-Kendall Trend Test for Autocorrelated Data. J. Hydrol. 204 (1-4), 182-196. doi:10.1016/s00221694(97)00125-x

Hawcroft, M. K., Shaffrey, L. C., Hodges, K. I., and Dacre, H. F. (2012). How Much Northern Hemisphere Precipitation Is Associated with Extratropical Cyclones?. Geophys. Res. Lett. 39 (24), 1-6. doi:10.1029/2012gl053866

Hawcroft, M., Walsh, E., Hodges, K., and Zappa, G. (2018). Significantly Increased Extreme Precipitation Expected in Europe and North America from Extratropical Cyclones. Environ. Res. Lett. 13 (12), 124006. doi:10.1088/1748-9326/aaed59

Hendry, A., Haigh, I. D., Nicholls, R. J., Winter, H., Neal, R., Wahl, T., et al. (2019). Assessing the Characteristics and Drivers of Compound Flooding Events Around the UK Coast. Hydrol. Earth Syst. Sci. 23 (7), 3117-3139. doi:10.5194/hess-23-3117-2019

Hong Kong Observatory (2017).. Super Typhoon Hato (1713) 20 to 24 August 2017. Retrieved September 24, 2020, from Available at: https://www.weather. gov.hk/informtc/hatol7/report.html.

Horsburgh, K. J., and Wilson, C. (2007). Tide-surge Interaction and its Role in the Distribution of Surge Residuals in the North Sea. J. Geophys. Res. Oceans 112 (8), 1-13. doi:10.1029/2006jc004033

Huntingford, C., Marsh, T., Scaife, A. A., Kendon, E. J., Hannaford, J., Kay, A. L., et al. (2014). Potential Influences on the United Kingdom's Floods of winter 2013/14. Nat. Clim Change 4 (9), 769-777. doi:10.1038/nclimate2314

Iannuccilli, M., Bartolini, G., Betti, G., Crisci, A., Grifoni, D., Gozzini, B., et al. (2021). Extreme Precipitation Events and Their Relationships with Circulation Types in Italy. Int. J. Climatol, 1-25. doi:10.1002/joc.7109

Ikeuchi, H., Hirabayashi, Y., Yamazaki, D., Muis, S., Ward, P. J., Winsemius, H. C., et al. (2017). Compound Simulation of Fluvial Floods and Storm Surges in a Global Coupled River-Coast Flood Model: Model Development and its Application to 2007 Cyclone Sidr in Bangladesh. J. Adv. Model. Earth Syst. 9 (4), 1847-1862. doi:10.1002/2017ms000943

Jane, R., Cadavid, L., Obeysekera, J., and Wahl, T. (2020). Multivariate Statistical Modelling of the Drivers of Compound Flood Events in South Florida. Nat. Hazards Earth Syst. Sci. 20 (10), 2681-2699. doi:10.5194/nhess-20-2681-2020

Kalnay, E., Kanamitsu, M., Kistler, R., Collins, W., Deaven, D., Gandin, L., et al. (1996). The NCEP/NCAR 40-year Reanalysis Project. Bull. Amer. Meteorol. Soc. 77 (3), 437-471. doi:10.1175/1520-0477(1996)077<0437:tnyrp>2.0.co;2

Karim, M., and Mimura, N. (2008). Impacts of Climate Change and Sea-Level Rise on Cyclonic Storm Surge Floods in Bangladesh. Glob. Environ. Change 18 (3), 490-500. doi:10.1016/j.gloenvcha.2008.05.002

Khanam, M., Sofia, G., Koukoula, M., Lazin, R., Nikolopoulos, E. I., Shen, X., et al. (2021). Impact of Compound Flood Event on Coastal Critical Infrastructures Considering Current and Future Climate. Nat. Hazards Earth Syst. Sci. 21 (2), 587-605. doi:10.5194/nhess-21-587-2021

Khouakhi, A., Villarini, G., and Vecchi, G. A. (2017). Contribution of Tropical Cyclones to Rainfall at the Global Scale. J. Clim. 30 (1), 359-372. doi:10.1175/ jcli-d-16-0298.1

Klotzbach, P. J., Bowen, S. G., Pielke, R., and Bell, M. (2018). Continental U.S. Hurricane Landfall Frequency and Associated Damage: Observations and Future Risks. Bull. Am. Meteorol. Soc. 99 (7), 1359-1376. doi:10.1175/bams-d-17-0184.1

Kunkel, K. E., Karl, T. R., Squires, M. F., Yin, X., Stegall, S. T., and Easterling, D. R. (2020). Precipitation Extremes: Trends and Relationships with Average Precipitation and Precipitable Water in the Contiguous United States. J. Appl. Meteorology Climatology 59 (1), 125-142. doi:10.1175/jamc-d-19-0185.1

Kurniadi, A., Weller, E., Min, S. K., and Seong, M. G. (2021). Independent ENSO and IOD Impacts on Rainfall Extremes over Indonesia. Int. J. Climatol 41 (6), 3640-3656. doi:10.1002/joc.7040

Lai, Y., Li, J., Gu, X., Chen, Y. D., Kong, D., Gan, T. Y., et al. (2020). Greater Flood Risks in Response to Slowdown of Tropical Cyclones over the Coast of China. Proc. Natl. Acad. Sci. USA 117 (26), 14751-14755. doi:10.1073/pnas.1918987117

Leonard, M., Westra, S., Phatak, A., Lambert, M., van den Hurk, B., Mcinnes, K., et al. (2014). A Compound Event Framework for Understanding Extreme Impacts. Wires Clim. Change 5 (1), 113-128. doi:10.1002/wcc.252
Li, J., Zhang, Q., Chen, Y. D., and Singh, V. P. (2015). Future Joint Probability Behaviors of Precipitation Extremes across China: Spatiotemporal Patterns and Implications for Flood and Drought Hazards. Glob. Planet. Change 124, 107-122. doi:10.1016/j.gloplacha.2014.11.012

Li, J., Zhang, Q., Chen, Y. D., and Singh, V. P. (2013). GCMs-Based Spatiotemporal Evolution of Climate Extremes during the 21stcentury in China. J. Geophys. Res. Atmos. 118 (19), 11017-11035. doi:10.1002/jgrd.50851

Lian, J. J., Xu, K., and Ma, C. (2013). Joint Impact of Rainfall and Tidal Level on Flood Risk in a Coastal City with a Complex River Network: A Case Study of Fuzhou City, China. Hydrol. Earth Syst. Sci. 17 (2), 679-689. doi:10.5194/hess-17-679-2013

Lim, E.-P., and Simmonds, I. (2007). Southern Hemisphere winter Extratropical Cyclone Characteristics and Vertical Organization Observed with the ERA-40 Data in 1979-2001. J. Clim. 20 (11), 2675-2690. doi:10.1175/jcli4135.1

Liu, M., Vecchi, G. A., Smith, J. A., and Murakami, H. (2017). The Present-Day Simulation and Twenty-First-century Projection of the Climatology of Extratropical Transition in the North Atlantic. J. Clim. 30 (8), 2739-2756. doi:10.1175/jcli-d-16-0352.1

Mawdsley, R. J., and Haigh, I. D. (2016). Spatial and Temporal Variability and Long-Term Trends in Skew Surges Globally. Front. Mar. Sci. 3, 1-17. doi:10.3389/fmars.2016.00029

Menne, M. J., Durre, I., Vose, R. S., Gleason, B. E., and Houston, T. G. (2012). An Overview of the Global Historical Climatology Network-Daily Database. J. Atmos. Oceanic Tech. 29 (7), 897-910. doi:10.1175/jtech-d-11-00103.1

Milly, P. C. D., Betancourt, J., Falkenmark, M., Hirsch, R. M., Kundzewicz, Z. W., Lettenmaier, D. P., et al. (2008). Stationarity Is Dead: Whither Water Management?. Science 319 (5863), 573-574. doi:10.1126/science.1151915

Moftakhari, H. R., Salvadori, G., AghaKouchak, A., Sanders, B. F., and Matthew, R. A. (2017). Compounding Effects of Sea Level Rise and Fluvial Flooding. Proc. Natl. Acad. Sci. USA 114 (37), 9785-9790. doi:10.1073/pnas.1620325114

Moftakhari, H., Schubert, J. E., AghaKouchak, A., Matthew, R. A., and Sanders, B. F. (2019). Linking Statistical and Hydrodynamic Modeling for Compound Flood hazard Assessment in Tidal Channels and Estuaries. Adv. Water Resour. 128, 28-38. doi:10.1016/j.advwatres.2019.04.009

Muis, S., Haigh, I. D., Guimarães Nobre, G., Aerts, J. C. J. H., and Ward, P. J. (2018). Influence of El Niño-Southern Oscillation on Global Coastal Flooding. Earth's Future 6 (9), 1311-1322. doi:10.1029/2018ef000909

Neumann, B., Vafeidis, A. T., Zimmermann, J., and Nicholls, R. J. (2015). Future Coastal Population Growth and Exposure to Sea-Level Rise and Coastal Flooding - A Global Assessment. PLoS ONE 10 (3). doi:10.1371/journal.pone.0118571

Pawlowicz, R., Beardsley, B., and Lentz, S. (2002). Classical Tidal Harmonic Analysis Including Error Estimates in MATLAB Using T_TIDE. Comput. Geosciences 28 (8), 929-937. doi:10.1016/s0098-3004(02)00013-4

Pinto, J. G., Gómara, I., Masato, G., Dacre, H. F., Woollings, T., and Caballero, R. (2014). Large-scale Dynamics Associated with Clustering of Extratropical Cyclones Affecting Western Europe. J. Geophys. Res. Atmos. 119 (24), 13704-13719. doi:10.1002/2014jd022305

Raymond, C., Horton, R. M., Zscheischler, J., Martius, O., AghaKouchak, A., Balch, J., et al. (2020). Understanding and Managing Connected Extreme Events. Nat. Clim. Chang. 10 (7), 611-621. doi:10.1038/s41558-020-0790-4

Ridder, N. N., Pitman, A. J., Westra, S., Ukkola, A., Hong, X. Do., Bador, M., et al. (2020). Global Hotspots for the Occurrence of Compound Events. Nat. Commun. 11 (1), 1-10. doi:10.1038/s41467-020-20502-8

Sen, P. K. (1968). Estimates of the Regression Coefficient Based on Kendall's Tau. J. Am. Stat. Assoc. 63 (3), 1379-1389. doi:10.1080/01621459.1968.10480934

She, D., Shao, Q., Xia, J., Taylor, J. A., Zhang, Y., Zhang, L., et al. (2015). Investigating the Variation and Non-stationarity in Precipitation Extremes Based on the Concept of Event-Based Extreme Precipitation. J. Hydrol. 530, 785-798. doi:10.1016/j.jhydrol.2015.10.029

Svensson, C., and Jones, D. A. (2002). Dependence between Extreme Sea Surge, River Flow and Precipitation in Eastern Britain. Int. J. Climatol. 22 (10), 1149-1168. doi:10.1002/joc.794

Svensson, C., and Jones, D. A. (2004). Dependence between Sea Surge, River Flow and Precipitation in South and West Britain. Hydrol. Earth Syst. Sci. 8 (5), 973-992. doi:10.5194/hess-8-973-2004

Towey, K. L., Booth, J. F., Frei, A., and Sinclair, M. R. (2018). Track and Circulation Analysis of Tropical and Extratropical Cyclones that Cause strong Precipitation and Streamflow Events in the New York City Watershed. J. Hydrometeorology 19 (6), 1027-1042. doi:10.1175/jhm-d-17-0199.1 
Tramblay, Y., Villarini, G., and Zhang, W. (2020). Observed Changes in Flood hazard in Africa. Environ. Res. Lett. 15 (10), 1040b5. doi:10.1088/1748-9326/ abb90b

Van Den Hurk, B., Van Meijgaard, E., De Valk, P., Van Heeringen, K.-J., and Gooijer, J. (2015). Analysis of a Compounding Surge and Precipitation Event in the Netherlands. Environ. Res. Lett. 10 (3), 035001. doi:10.1088/1748-9326/10/ $3 / 035001$

Vousdoukas, M. I., Mentaschi, L., Voukouvalas, E., Verlaan, M., Jevrejeva, S., Jackson, L. P., et al. (2018). Global Probabilistic Projections of Extreme Sea Levels Show Intensification of Coastal Flood hazard. Nat. Commun. 9 (1), 2360. doi:10.1038/s41467-018-04692-w

Wahl, T., Jain, S., Bender, J., Meyers, S. D., and Luther, M. E. (2015). Increasing Risk of Compound Flooding from Storm Surge and Rainfall for Major US Cities. Nat. Clim Change 5 (12), 1093-1097. doi:10.1038/nclimate2736

Walsh, K. J. E., McBride, J. L., Klotzbach, P. J., Balachandran, S., Camargo, S. J., Holland, G., et al. (2016). Tropical Cyclones and Climate Change. Wires Clim. Change 7 (1), 65-89. doi:10.1002/wcc.371

Wang, Q., Xu, Y., Wei, N., Wang, S., and Hu, H. (2019). Forecast and Service Performance on Rapidly Intensification Process of Typhoons Rammasun (2014) and Hato (2017). Trop. Cyclone Res. Rev. 8 (1), 18-26. doi:10.1016/ j.tcrr.2019.07.002

Ward, P. J., Couasnon, A., Eilander, D., Haigh, I. D., Hendry, A., Muis, S., et al. (2018). Dependence between High Sea-Level and High River Discharge Increases Flood hazard in Global Deltas and Estuaries. Environ. Res. Lett. 13 (8). doi:10.1088/1748-9326/aad400

Weisse, R., von Storch, H., Niemeyer, H. D., and Knaack, H. (2012). Changing North Sea Storm Surge Climate: An Increasing hazard?. Ocean Coastal Manag. 68, 58-68. doi:10.1016/j.ocecoaman.2011.09.005

Williams, J., Horsburgh, K. J., Williams, J. A., and Proctor, R. N. F. (2016). Tide and Skew Surge independence: New Insights for Flood Risk. Geophys. Res. Lett. 43 (12), 6410-6417. doi:10.1002/2016gl069522

Wong, M. L. M., and Chan, J. C. L. (2004). Tropical Cyclone Intensity in Vertical Wind Shear. J. Atmos. Sci. 61 (15), 1859-1876. doi:10.1175/1520-0469(2004) $061<1859$ :tciivw $>2.0$. co;2

Woodworth, P. L., Hunter, J. R., Marcos, M., Caldwell, P., Menéndez, M., and Haigh, I. (2016). Towards a Global Higher-Frequency Sea Level Dataset. Geosci. Data J. 3 (2), 50-59. doi:10.1002/gdj3.42

$\mathrm{Xu}, \mathrm{H}$., Xu, K., Bin, L., Lian, J., and Ma, C. (2018). Joint Risk of Rainfall and Storm Surges during Typhoons in a Coastal City of Haidian Island, China. Int. J. Environ. Res. Public Health 15 (7). doi:10.3390/ijerph15071377

Xu, H., Xu, K., Lian, J., and Ma, C. (2019). Compound Effects of Rainfall and Storm Tides on Coastal Flooding Risk. Stoch Environ. Res. Risk Assess. 33 (7), 1249-1261. doi:10.1007/s00477-019-01695-x

Yanase, W., and Niino, H. (2015). Idealized Numerical Experiments on Cyclone Development in the Tropical, Subtropical, and Extratropical Environments. J. Atmos. Sci. 72 (9), 3699-3714. doi:10.1175/jas-d-15-0051.1

Yanase, W., and Niino, H. (2019). Parameter Sweep Experiments on a Spectrum of Cyclones with Diabatic and Baroclinic Processes. J. Atmos. Sci. 76 (7), 1917-1935. doi:10.1175/jas-d-18-0232.1

You, Q., Kang, S., Aguilar, E., Pepin, N., Flügel, W.-A., Yan, Y., et al. (2011). Changes in Daily Climate Extremes in China and Their Connection to the Large
Scale Atmospheric Circulation during 1961-2003. Clim. Dyn. 36 (11-12), 2399-2417. doi:10.1007/s00382-009-0735-0

Yu, Y. C., Chen, H., Shih, H. J., Chang, C. H., Hsiao, S. C., Chen, W. B., et al. (2019). Assessing the Potential Highest Storm Tide hazard in Taiwan Based on 40-year Historical Typhoon Surge Hindcasting. Atmosphere 10 (6). doi:10.3390/ atmos 10060346

Zhai, P., Zhang, X., Wan, H., and Pan, X. (2005). Trends in Total Precipitation and Frequency of Daily Precipitation Extremes over China. J. Clim. 18 (7), 1096-1108. doi:10.1175/jcli-3318.1

Zhang, Q., Li, J., Gu, X., and Shi, P. (2018b). Is the Pearl River basin, China, Drying or Wetting? Seasonal Variations, Causes and Implications. Glob. Planet. Change 166, 48-61. doi:10.1016/j.gloplacha.2018.04.005

Zhang, Q., Li, J., Singh, V. P., and Xu, C.-Y. (2013). Copula-based Spatio-Temporal Patterns of Precipitation Extremes in China. Int. J. Climatol. 33 (5), 1140-1152. doi:10.1002/joc.3499

Zhang, W., Vecchi, G. A., Murakami, H., Villarini, G., Delworth, T. L., Yang, X., et al. (2018a). Dominant Role of Atlantic Multidecadal Oscillation in the Recent Decadal Changes in Western North Pacific Tropical Cyclone Activity. Geophys. Res. Lett. 45 (1), 354-362. doi:10.1002/2017gl076397

Zhang, W., Villarini, G., Vecchi, G. A., and Smith, J. A. (2018c). Urbanization Exacerbated the Rainfall and Flooding Caused by hurricane Harvey in Houston. Nature 563 (7731), 384-388. doi:10.1038/s41586-018-0676-Z

Zhang, W. Z., Shi, F., Hong, H. S., Shang, S. P., and Kirby, J. T. (2010). Tide-surge Interaction Intensified by the Taiwan Strait. J. Geophys. Res. Oceans 115 (6), 1-17. doi:10.1029/2009jc005762

Zhang, X., Aguilar, E., Sensoy, S., Melkonyan, H., Tagiyeva, U., Ahmed, N., et al. (2005). Trends in Middle East Climate Extreme Indices from 1950 to 2003. J. Geophys. Res. Atmospheres 110 (22), 1-12. doi:10.1029/ 2005jd006181

Zhang, X., Alexander, L., Hegerl, G. C., Jones, P., Tank, A. K., Peterson, T. C., et al. (2011). Indices for Monitoring Changes in Extremes Based on Daily Temperature and Precipitation Data. Wires Clim. Change 2 (6), 851-870. doi:10.1002/wcc.147

Zheng, F., Westra, S., and Sisson, S. A. (2013). Quantifying the Dependence between Extreme Rainfall and Storm Surge in the Coastal Zone. J. Hydrol. 505, 172-187. doi:10.1016/j.jhydrol.2013.09.054

Zscheischler, J., Westra, S., Van Den Hurk, B. J. J. M., Seneviratne, S. I., Ward, P. J. Pitman, A., et al. (2018). Future Climate Risk from Compound Events. Nat. Clim Change 8 (6), 469-477. doi:10.1038/s41558-018-0156-3

Conflict of Interest: The authors declare that the research was conducted in the absence of any commercial or financial relationships that could be construed as a potential conflict of interest.

Copyright (c) $2021 \mathrm{Lai}, \mathrm{Li}, \mathrm{Li}$, Zhou, Zhang and Wu. This is an open-access article distributed under the terms of the Creative Commons Attribution License (CC BY). The use, distribution or reproduction in other forums is permitted, provided the original author(s) and the copyright owner(s) are credited and that the original publication in this journal is cited, in accordance with accepted academic practice. No use, distribution or reproduction is permitted which does not comply with these terms. 